\title{
PROPUESTA DIDÁCTICA: HERRAMIENTA METODOLÓGICA Y DIDÁCTICA PARA ANALIZAR TEXTOS LITERARIOS CON SÉTIMOS AÑOS
}

\author{
Catalina Ramírez Molina \\ Profesora de la Escuela de Formación Docente \\ de la Universidad de Costa Rica \\ San José, Costa Rica
}

Recibido 10-XII-2007 • Aceptado 13-XI-2007 • Corregido 2-III-2007

"La inteligencia consiste no solo en el conocimiento, sino también en la destreza de aplicar los conocimientos en la práctica".

Aristóteles

\begin{abstract}
Resumen: En el artículo titulado Estrategias metodológicas utilizadas por docentes de sétimo año en la enseñanza del análisis de textos literarios se plantean varias interrogantes con respecto a la enseñanza de la literatura, dos de ellas son: ¿Cómo enseñar literatura en el contexto de una enseñanza obligatoria y cómo acercar a los adolescentes a la lectura y al disfrute de los textos literarios? y ¿Cómo los docentes pueden acercarse al horizonte de expectativas de unos adolescentes cada vez más interesados en el consumo de otros usos comunicativos? Estas interrogantes y el diagnóstico realizado exponen una necesidad de crear una didáctica específica para enseñar literatura que reúna el conocimiento sobre el objeto a enseñar, en este caso, la literatura, y los modos de enseñarla, es decir, su metodología.

De esta manera, el propósito de la presente propuesta didáctica es contribuir a que los estudios literarios se orienten a acercarse a las expectativas y hábitos culturales del alumnado.

La propuesta que se plantea es una alternativa teórico-didáctica, que consta del desarrollo de cuatro fases, que se ponen en práctica durante el primer trimestre del curso lectivo, de sétimo año.
\end{abstract}

\section{Introducción}

Mediante el diagnóstico del estado de situación de la enseñanza y aprendizaje de los textos literarios en el nivel de sétimo año, que se analizó en el artículo titulado Estrategias metodológicas utilizadas por docentes de sétimo año en la enseñanza del análisis de textos literarios (Ramírez, 2007), se constató - por medio de entrevistas y observaciones a estudiantes y docentes; la revisión y análisis del programa de estudios de Español, en el área de literatura, que plantea el Ministerio de Educación Pública y el análisis de libros de texto utilizados en secundaria-, que la forma en que se enseña la literatura indispone de antemano a los estudiantes, causando desinterés. Ante esta situación, la propuesta que se plantea 
Palabras clave: Propuesta, enseñanza de la literatura, metodología, docentes, estudiantes.

\begin{abstract}
In the article Methodological Strategies Used by 7 th Grade Instructors to Teach the Analysis of Literary Texts some questions came up related to the teaching of literature. Two of those questions are: a) How to teach literature in the context of a mandatory school system and how to make young students get closer to the reading and enjoyment of literary texts?, and b) how can teachers move closer to the whole array of expectations that adolescents have in their ever expanding interest in the use of other communicative media? The answers to these questions and their subsequent diagnosis bring out the need to create a specific approach for the teaching of literature which includes the knowledge about the object of study, i.e. literature, and the ways to teach it, namely, its methodology.

In this way, the purpose of the present didactic proposal is to orient literary scholarship towards the fulfillment of the students' expectations and cultural habits.

This is a theoretical and pedagogical proposal that includes the development of four phases that could take place during the first trimester of the academic year in $7^{\text {th }}$ graders.
\end{abstract}

Keywords: Proposal, teaching of literature, methodology, teachers, students. en este artículo es una alternativa teóricodidáctica, que consta del desarrollo de cuatro fases, para poner en práctica durante el primer trimestre del curso lectivo de sétimo año. El propósito es que a través de la creación de una herramienta metodológica y didáctica, los estudiantes sientan el deseo de acercarse y disfrutar de la literatura, al mismo tiempo, que puedan distinguir, discriminar y valorar su entorno sociocultural.

No cabe duda de que una adecuada enseñanza literaria depende tanto de la estrategia como de la buena comprensión del texto literario; en este sentido, la educación literaria consiste en la adquisición y en el desarrollo de esta capacidad específica y no sólo en la transmisión de un legado literario de obras y autores consagrados por la tradición académica.

Tomando en cuenta este criterio, la propuesta teórico-didáctica consta de cuatro fases: la primera fase se titula Concientización sobre la importancia de la lengua y la literatura. La intención de esta primera parte es que los estudiantes comprendan el objeto de estudio y sientan la necesidad de apropiarse de él, es decir, que logren comprender la importancia de desarrollar su competencia comunicativa y literaria.

La segunda fase se titula Conceptualización de la literatura. A través de ella, se pretende que los estudiantes realicen un recorrido histórico sobre el origen del concepto de literatura, de esta manera, conocerán y manejarán diversas nociones sobre el objeto de estudio.

La tercera fase se titula Adquisición de habilidades de lectura. El propósito de ésta es que los alumnos adquieran habilidades de lectura, que logren diversos acercamientos al texto literario y disfruten de ese proceso.

La última fase se titula ¿Cómo realizar análisis literario? En ésta, se busca que el docente guíe el análisis literario, pero quienes lo construirán, son los alumnos. Si se han seguido las fases anteriores, los estudiantes estarán listos para desarrollarla, ya 
que han pasado por el proceso de concientización y conceptualización de lo que es literatura y han adquirido habilidades de lectura, es decir, se encuentran preparados para profundizar en el texto literario.

El desarrollo del CCAA (Concientización, Conceptualización, Adquisición y Análisis literario) consta de propósitos, un objetivo general, objetivos específicos, contenidos, estrategias y actividades de aprendizaje, valores y actitudes, criterios de evaluación, tiempo, materiales y bibliografía.

Para efectos de este artículo, se expondrá el propósito, el objetivo general, los objetivos específicos, los contenidos y las actividades de cada fase. En la última fase se incluyen tres planeamientos diferentes, uno para cada género literario: poesía, cuento y novela, los cuales serán explicados en el artículo Propuesta para analizar el cuento El gato negro de Edgar Allan Poe, La novela Marianela de Benito Pérez Galdós y las Rimas de Gustavo Adolfo Bécquer (Ramírez, 2007).

Es importante señalar que esta propuesta se ha confeccionado, tomando en cuenta los recursos tecnológicos, la población estudiantil y docente del Liceo de Heredia, ya que en esta institución se realizó el estudio. Actualmente, el Liceo de Heredia posee tres laboratorios de cómputo, una biblioteca, una aula de videoconferencia, pizarra inteligente, proyector de multimedia, proyector de opacos, dvd, grabadora, microscopio electrónico, entre otras.

El Liceo de Heredia cuenta con una población estudiantil de 1616 estudiantes. En sétimo año, que es la población en estudio, se ubican 441 estudiantes. El cuerpo docente está integrado por 70 docentes, de los cuales seis pertenecen al Departamento de Español.

En la investigación se trabajó con el $100 \%$ de la población de docentes que imparten, únicamente, el nivel de sétimo año, el cual corresponde a dos profesoras.

Esta población de docentes posee categoría de MT4. Concluyeron sus estudios de Bachillerato en la Universidad Nacional y tienen, aproximadamente, diecisiete años de trabajar como docentes de Español en el Liceo de Heredia, aunque trabajaron en otros colegios al inicio de sus carreras.

Los sujetos que se observaron son estudiantes de sétimo año. Poseen una edad aproximada entre los 12 a los 14 años. La mayoría proviene del centro de Heredia: la Puebla, Mercedes Norte, Barrio Fátima. Se considera que el nivel económico es de clase baja a clase media-baja.

\section{Primera Fase: \\ Concientización sobre la importancia de la lengua y la literatura}

Carlos Lomas (1999, p. 90), en su artículo Cómo enseñar a hacer cosas con las palabras, señala que los estudios sobre la literatura se caracterizan por un absoluto desacuerdo entre las diversas tendencias y enfoques de la teoría literaria, asimismo, con las opiniones en torno a la educación literaria y a los métodos pedagógicos más adecuados para enseñar literatura en la enseñanza secundaria.

Coincide Solano (2000, p. 151) en su artículo El proceso de enseñanza-aprendizaje de la lectura; al señalar que en Costa Rica, la educación literaria en secundaria, representa débiles esfuerzos. Para esta autora, el sistema educativo de nuestro país no ha logrado formar el hábito de la lectura; no se encuentra un enfoque específico en la comprensión lectora y se presenta un desarrollo impositivo, mecánico y superficial de la lectura, por parte de los docentes y los programas de Español planteados por el Ministerio de Educación Pública, lo que provoca la incapacidad para despertar la criticidad y la motivación de leer en los estudiantes.

Asimismo, un estudio realizado por Carlos Sánchez Lozano, de la Universidad Sergio Arboleda, en Bogotá -en una encuesta realizada por esta universidad-, 
muestra que los jóvenes no aparecen como lectores habituales. Sin embargo, parte de los encuestados, señalan que les gustaría leer más, si no los obligaran a analizar textos que no despiertan su interés. Ante esta respuesta Sánchez señala:

No podemos hablar de un franco distanciamiento de los jóvenes hacia los libros, ni concluir que la cultura audiovisual o internet los atrapó volviéndolos alfabetos funcionales, dominados por las nuevas tecnologías (Sánchez, 2005, p. 1).

Esta perspectiva apunta a que los estudiantes gustan de la lectura pero no están dispuestos a leer aquello que no los inspira o que no despierta sus intereses.

$\mathrm{Al}$ respecto Solano (2000, p. 154) señala que el docente debe facilitar a sus alumnos experiencias de lectura que promuevan la formación de intereses y aficiones, sin embargo, afirma que éstos, actualmente, leen solamente como un ejercicio visual obligatorio y no como herramienta de enriquecimiento intelectual, social, cultural y, sobre todo, recreativo. Esto genera en el educando una actitud negativa hacia el acto de leer.

Ante esta situación, Sánchez (2005, p. 1) considera cuatro principios básicos para que el estudiante se acerque al libro: (1) querer leerlo, (2) poseer los conocimientos previos para enfrentar el texto, (3) tener habilidades lingüísticas que permitan qué hacer si no se entiende el texto, es decir, adquirir la posibilidad de reflexión y finalmente (4) tener con quien conversar sobre lo leído. En esta dirección, Sánchez señala que "No es que los estudiantes no sepan leer", sino que están en vías de aprender a hacerlo. Esta competencia no nace con ellos, la aprenden. Por esta razón necesitan de la mediación docente para llevar a cabo este proceso.

Por otra parte, Vindas y Alvarado (1999, p. 135), en su artículo Un cambio de paradigma en la enseñanza de la lectura y la escritura, consideran que el contexto de los estudiantes afecta directamente la forma en que ellos construyen el texto. En sus palabras, dejar de lado el contexto equivale a eliminar un factor clave para la construcción del significado, en este sentido, las autoras señalan que:

El contexto forma parte de cualquier acto de lectura, influyendo sobre los significados que construyen los lectores cuando tratan de coordinar todas las fuentes de conocimiento de que disponen (Vindas y Alvarado, 1999, p. 156).

Para estas autoras el acto de enseñanza de la lectura ha descendido, ya que "a pesar de la cantidad de investigación dedicada a la comprensión lectora, quedan todavía por implantarse los cambios necesarios en la forma de enseñarla" (Vindas y Alvarado, 1999, p. 157).

En este sentido las autoras antes mencionadas, al igual que Palacios y Picado (2004, p. 120), en su estudio Metodología alternativa para analizar el texto El Ingenioso Hidalgo Don Quijote de la Mancha en $10^{\circ}$ año de la Educación Diversificada, coinciden en que:

Las distintas metodologías de enseñanza de la literatura se confrontan en una dicotomía en la que no se llega a un acuerdo acerca de cuál es la mejor manera de enseñar y aprender un texto literario: de forma conductista (clases magistrales, cuestionarios, guías de lectura...) o bien, a la manera constructivista y significativa que implica tácticas alternativas, desde lo lúdico hasta la recreación artística del texto para motivarlo (Palacios y Picado, 2004, p. 24).

Asimismo, Teresa Colomer (1995, p. 133), señala que:

Leer es un acto interpretativo que consiste en saber guiar una serie de razonamientos hacia la construcción de una interpretación del mensaje escrito a partir tanto de la información que proporciona el texto como de los conocimientos del lector.

\section{El propósito}

Considerando las afirmaciones anteriores y lo analizado en el artículo titulado Estrategias metodológicas utilizadas por docentes de sétimo año en la enseñanza del análisis de textos literarios (Ramírez, 
2007), los estudiantes ingresan a secundaria sin tener claro qué es la literatura y por qué es importante su estudio.

Por esta razón, la primera fase tiene como propósito que el educando reflexione sobre qué es lo que debe aprender y cómo podría conversar con el texto literario al leer. Es decir, el estudiantado necesita conocer qué aprenderá y para qué, saber qué hacer con el texto y entender lo que lee. En este sentido, el alumno se preguntará, cómo puede construir su aprendizaje literario incluyendo conocimientos, habilidades, hábitos y actitudes.

De esta manera, al mismo tiempo que se muestra la importancia de adquirir habilidades como lectores para sobrevivir en un mundo globalizado, se intentará animar a los adolescentes no sólo a leer textos literarios sino también a discriminar la información que reciben diariamente.

En esta fase se pretende que los estudiantes sientan la necesidad de apropiarse de ciertas herramientas del lenguaje, adquisición de técnicas y de estrategias, que le permitirán ser una persona crítica, creativa y sobre todo que logre generar en su sistema cognitivo, preguntas, reflexiones, afirmaciones, ideas, sentimientos y vivencias como sujeto social. En esta línea, se espera que el alumno comprenda la importancia de desarrollar su competencia comunicativa y literaria.

\section{Objetivo general}

El estudiante comprenderá la importancia de adquirir y desarrollar una competencia comunicativa y literaria, a través de habilidades de lectura con el propósito de disfrutar y de comprender distintos textos literarios y otros usos comunicativos.

\section{Objetivos específicos}

El estudiante

1. Inferirá que a través del manejo y conocimiento consciente de su lengua y de la literatura podrá apropiarse de herramientas útiles para desenvolverse en un mundo globalizado e informatizado.

2. Reconocerá diversas formas en las que diariamente está en contacto con la lengua.

3. Identificará los elementos del proceso de comunicación: emisor, receptor, mensaje, código, canal, contexto, referente, con el fin de comprender el hecho comunicativo en la vida cotidiana y en el texto literario.

\section{Contenidos}

1. El hecho comunicativo en la vida cotidiana: radio, televisión, internet, periódicos, colegio, supermercado, entre otras.

2. Formas básicas de comunicación humana: comunicación verbal o lingüística y comunicación no verbal.

3. Proceso de comunicación: emisor, receptor, mensaje, código, canal, contexto, referente.

4. Lenguaje en la interacción social: el acto de habla, enunciado, acto comunicativo.

\section{Actividades}

Las actividades que se realizarán para el desarrollo de esta fase son:

- En las primeras lecciones del curso lectivo, la docente se encargará de llevar a sus estudiantes al Aula Virtual. En el caso del Liceo de Heredia, se cuenta con este recurso. Sin embargo, si la institución no lo posee, la docente los puede dirigir a la biblioteca o al aula. 
- A través de una presentación audiovisual elaborada por la docente, por medio del programa PowerPoint, se proyectarán, de manera animada, frases y afirmaciones que los estudiantes escuchan diariamente. (Ver Anexo 2 en filmina 2 , p. 155, Ramírez, 2007, tesis de Licenciatura). Las frases y afirmaciones pueden ser expuestas por la docente en papel cartulina en el aula.

- Luego se plantearán preguntas mediante las cuales se cuestionará al estudiante con respecto a su relación con la lengua (Ver Anexo 2 en filminas 4-19, p. 157-172).

- Posteriormente en la presentación audiovisual se mostrarán apreciaciones de algunos autores con respecto al lenguaje (Ver Anexo 2 en filminas 21-25, p. 127-178).

- $\quad$ Seguidamente, se les solicitará a los estudiantes que cierren sus ojos para realizar un ejercicio.

- Éste consiste en que, a través de la música aún existente en la presentación audiovisual, logren evocar imágenes, con el propósito de mostrarles que también a través de la literatura, el ser humano es capaz de imaginar lo que lee.

- Al finalizar este ejercicio, el grupo de estudiantes formará un círculo de discusión. La docente preguntará qué tipo de imágenes pudieron evocar. Asimismo, cada uno opinará sobre las preguntas y las apreciaciones del lenguaje que se mostraron en la presentación audiovisual.

- Mediante la lluvia de ideas, se tomarán en cuenta las opiniones del grupo.

- $\quad$ Finalmente, la docente se encargará de cerrar el círculo de discusión reto- mando las ideas sugeridas por los estudiantes y explicará la importancia de la lengua en la vida cotidiana, en el hecho comunicativo, en quiénes intervienen en él y de qué manera.

A través de estas actividades se cumplen los objetivos específicos 1,2 y 3 , y los contenidos del 1al 4.

A través del desarrollo de esta fase se pretende que los estudiantes logren comprender la importancia de acercarse a su propia lengua para que puedan desenvolverse como sujetos críticos y creativos, al mismo tiempo, tomando en cuenta su contexto, intereses y conocimientos, que adquieran un gusto especial por la literatura.

Asimismo, esta fase resulta indispensable para el desarrollo de las otras fases pues ¿Cómo iniciar la enseñanza de un conocimiento sin explicar a los estudiantes de qué se trata y para qué? Esta es una información que requieren para incentivar sus intereses, y los docentes, para analizar qué apreciaciones poseen con respecto al tema.

Por lo tanto, esta fase plantea un nivel básico e introductorio que permitirá un ordenamiento metodológico que facilite al alumnado una relación directa con el objeto de estudio.

\section{Segunda fase: Conceptualización de la literatura}

El vocablo literatura ha sido objeto de múltiples significados. Según Aguiar e Silva, autor clásico, reconocido por su aporte a la teoría literaria, en su texto Teoría de la Literatura (1968), señala que en latín, literatura significa instrucción, saber relacionado con el arte de escribir y leer. Posteriormente este vocablo inicia una evolución semántica que va desde el saber, ya no como cualidad de un sujeto, sino como 
un conjunto de objetos que se pueden estudiar, luego como un conjunto de obras literarias de un país, hasta la idea de creación estética, como categoría intelectual y forma específica de conocimiento.

Carlos Lomas (1999, pp. 97-100), en su artículo Cómo pensar en hacer cosas con las palabras, esboza los métodos que, a lo largo de la historia de la enseñanza de la literatura, han dominado la pedagogía de lo literario, es decir, realiza un breve análisis de la evolución de la historia de la enseñanza de la literatura. En este análisis Lomas señala:

- $\quad$ En la Edad Media hasta el siglo XIX, la educación literaria se orientaba en la adquisición de las habilidades de elocución. Se educaba en el uso correcto, adecuado y coherente del texto a la vez que la lectura de los clásicos grecolatinos suministraba los modelos expresivos que servían como ejemplos del buen decir y del buen escribir.

- En el siglo XIX hasta nuestros días, se concibe la literatura como un reflejo de la vida cotidiana. Es así como la literatura se orientó a la creación de una conciencia nacional y a la adhesión de la población escolar a las obras claves de la literatura de cada país.

- La influencia de este modelo permanece hasta hoy. Se concibe la educación literaria como el estudio académico de las obras, autores y movimientos literarios de la historia literaria y se orienta el aprendizaje de los conceptos y de los hechos literarios más relevantes.

- $\quad$ En la década de los sesenta, se presenta una insuficiencia de una enseñanza de la literatura incapaz de servir en el desarrollo del influjo de otras formas de comunicación y de otros mensajes asociados a la denominada "cultura de masas". Ante el cambio en los hábitos culturales de la adolescencia y el auge de las nuevas maneras de disfrutar el ocio, se replantea la idea de orientar la educación literaria hacia la adquisición de hábitos lectores y hacia la formación de actitudes positivas ante el texto literario. herramienta comunicativa mediante la cual las personas intentan dar sentido a la propia experiencia, construir su identidad individual y colectiva y utilizar el lenguaje de un modo creativo. En este sentido, se pone el acento en el placer de la lectura, la cual toma en consideración el horizonte de expectativas de los adolescentes.

- Sin embargo, la educación literaria en la actualidad, en su afán de favorecer el acceso de los alumnos a la experiencia literaria, ha enfrentado ciertas dificultades que aún no se resuelven (Lomas, 1999, pp. 97-100).

Para este autor saber literatura no es ya sólo conocer la historia literaria sino también dominar un conjunto de técnicas que hacen posible una adecuada comprensión del fondo y de la forma de las obras literarias. Desde este punto de vista, en la comprensión del texto, participan directamente los métodos de enseñanza del docente y las capacidades lectoras del estudiante.

En esta línea, Lomas plantea que la educación literaria no sólo debe transmitir el legado literario de las obras y autores consagrados por la tradición académica, sino que debe contribuir en el desarrollo de la competencia literaria de los estudiantes.

Es así como se puede inferir que la literatura, desde su emergencia, ha sufrido transformaciones conceptuales debido a las fluctuaciones sociales, económicas y culturales de cada época. En cada una se producen conceptos diferentes con respecto al término como consecuencia de los cambios históricos, culturales y económicos de la sociedad. En esta línea la literatura es una ficha vacía que va adquiriendo significado según la problemática histórico-social en la cual está inmersa y en la que se produce.

En palabras de Manuel Picado, en su texto Literatura Ideología Crítica (1983) la literatura:

No existe en virtud de una supuesta "literariedad" que ella manifestaría, sino gracias a la clasificación que una determinada sociedad efectúa sobre la masa de sus prácticas de lenguaje (Picado, 1983, p. 21). 
Desde esta perspectiva, la literatura no es una institución de las "bellas artes" como se pensaba, es decir, no es una representación estática de textos clasificados como literarios, ni un acontecimiento histórico, sino que su carácter es progresivo y productivo. Es por ello que la literatura debe entenderse, según Picado, como una práctica del discurso social que produce sus propias respuestas, y no como aquella que refleja y expresa "la realidad y la vida".

Asimismo, Mignolo, en su artículo Elementos para una teoría del texto literario (1978) considera que:

La literatura es un concepto vacío, donde las ambigüedades son inevitables debido a las propias características del concepto: al ser vacío, éste permite que se le interprete según la conveniencia de los presupuestos ideológicos que rigen el discurso en el cual se insertan (...) su definición, por lo tanto, es relativa al discurso que la conceptualiza. Creo, por esta razón, que no es posible definir el ser de la literatura sin referencia al ser del discurso que la define (Mignolo, 1978, p. 28).

Podría plantearse, por lo tanto, que el discurso, en tanto configuración semiótica estereotipada, funciona como una virtualidad comunicativa condicionada por la posición social y por las prácticas sociales existentes al interior de la sociedad, de esta forma, los discursos son agentes de programas de comunicación en la reproducción social vigente en cada formación histórica y con ella va caminando la literatura. Es así como el discurso está, necesariamente, contaminado por las ideologías, por esta razón, en el texto lo ideológico es el lugar a partir del cual habla el sujeto y desde el ángulo que habla.

Por otra parte, en la actualidad se presenta un rompimiento con lo tradicional y nacen nuevas perspectivas que miran a la literatura ya no como ángulo de la creación o del texto por el texto, sino que se contempla en el plano sociológico e ideológico.

Desde un enfoque sociológico, María Amoretti señala que:
La literatura, en tanto aparato, comprende una producción, un mercado y un consumo. Es práctica social en tanto es el resultado de una serie de selecciones operadas por diversos filtros sociales, económicos y culturales en los proyectos que los escritores han llevado a la etapa de la escritura. En contraposición con una noción idealista de la literatura (producto de una "misteriosa creación"), la literatura se concibe como un proceso material de una vida social dada (Amoretti, 1992, p. 16).

La cita anterior confirma el pensamiento de Manuel Picado al coincidir en que la literatura no es una creación misteriosa de un individuo aislado, tampoco la expresión de un espíritu nacional, sino un espacio en el cual se insertan pensamientos y acciones humanas, determinadas por un aparato ideológico, social, cultural e histórico del cual se forma parte y que su táctica será poner en crisis esas instituciones e ideologías tradicionales.

En este sentido, la literatura podrá entenderse, considerando las aseveraciones anteriores, no como un reflejo temático de lo que sucede en el mundo, sino como un discurso y una práctica sociales en donde el lenguaje es siempre cambiante, es decir, actúa en las transformaciones, revaluaciones e intercambios sociales en donde quienes escriben, quienes leen y quienes interpretan van redefiniendo lo que es la literatura. Asimismo, se entenderá que la lectura es un proceso en gran medida inferencial; un proceso de captación de "lo no dicho"; un proceso interpretativo resultado de una relación bidireccional entre el lector y el texto. Por lo tanto, la literatura será una producción significante construida a través del trabajo estético-ideológico con el lenguaje.

\section{El propósito}

El propósito de esta fase consiste en que los estudiantes comprendan el origen de la literatura y las diversas nociones que se han planteado a través de la historia. En este sentido, se pretende una concientización por parte de los alumnos, sobre la 
necesidad de articular la enseñanza de la literatura con los distintos eventos sociales, culturales y universales. Contextualizar las obras literarias y reflexionar sobre qué conexión existe entre el trabajo literario con el lenguaje y la función de la literatura en la sociedad. Sin embargo, esto no quiere decir que el docente debe ser un transmisor de toda esa información, sino que seleccionará y estudiará, en perspectiva histórica, el material literario, a través de la consulta de algunos autores y teóricos como: Carlos Lomas, Paula Carlino, Sánchez Corrales, A. Meix, F. entre otros; y en función de las necesidades de sus alumnos.

Esta fase, aunque densa conceptualmente, no implica una línea estrictamente cronológica sino más bien histórica de la literatura, lo que posibilitaría entender cambios tanto en la literatura, como en la significación de su escritura y lectura en mundos concretos.

Aunque se ha señalado, que el estudio de la historia de la literatura crea algunas actitudes hostiles en los estudiantes, esta fase se presenta como un intercambio interactivo, en donde el recorrido histórico se realiza de una manera agradable, interesante y relacionada con los intereses de los alumnos.

Es importante considerar que los educandos tienen ideas, representaciones y concepciones previas acerca de qué es literatura, originadas en sus experiencias culturales, dentro y fuera del colegio, las cuales influirán en el momento de enfrentarse con un texto literario durante una situación de lectura en el aula.

\section{Objetivo general}

El estudiante conocerá el origen de la literatura y explorará las diversas nociones de este concepto a través de la historia, con el propósito de comprenderla como una producción significante estético-ideológica construida con lenguaje, práctica y discurso sociales.

\section{Objetivos específicos}

El estudiante:

1. Realizará un recorrido por las diversas nociones del concepto de literatura.

2. Inferirá la importancia de la literatura como producción significante estético-ideológica.

3. Reconocerá la lengua literaria como un sistema ficcional, connotativo, plurisignificativo y como una manifestación dialógico-cultural.

\section{Contenidos}

1. Historia de la literatura: orígenes y transformaciones.

2. Concepto de texto.

3. Funciones de la literatura: estética, de entretenimiento, de conocimiento, social, educativa o pedagógica.

4. Características de la lengua literaria: ficcional, connotativa, plurisignificativa y dialógico-cultural.

\section{Actividades}

Como se mencionó en la presentación del propósito de esta fase, es indispensable partir de las representaciones de la literatura que tienen los alumnos. Por esta razón, la primera actividad que se podría realizar se titula "La telaraña".

Duración de la actividad: 2 lecciones.

- La telaraña es una dinámica participativa que la docente puede implementar en el aula. Esta consiste en solicitarle a los estudiantes que se pongan en pie y formen un círculo. La docente formulará la siguiente 
pregunta a sus estudiantes: ¿Qué es para ustedes la literatura?

Seguidamente, la profesora entregará a alguno de los integrantes del círculo una bola de cordel o un ovillo de lana. El alumno, toma la punta del cordel, responde a la pregunta y dejándose en su mano el inicio del ovillo, lanza la bola a otro compañero, quien a su vez debe responder la misma pregunta. La acción se repite hasta que todos los participantes queden enlazados en una especie de telaraña.

Una vez que todos han respondido a la pregunta, la docente cerrará la dinámica retomando las apreciaciones de los estudiantes, a través de una lluvia de ideas y señalará que la pregunta que formuló, es la que ha atravesado diferentes respuestas a través de la historia, como las que ellos han expuesto.

Por lo tanto, la tarea que tienen pendiente es disolver la telaraña a través de una visita a la biblioteca.

- La segunda actividad tiene una duración de 3 lecciones (2 en la biblioteca resolviendo el cuestionario y una en clase discutiendo) y consiste en visitar la biblioteca para que los alumnos puedan conocer las diversas definiciones de literatura y de este modo disolver la telaraña.

El acercamiento de los estudiantes a estas nociones no será al azar, sino que el docente deberá revisar y seleccionar el material útil disponible en la biblioteca. Posteriormente, facilitará un cuestionario de pocas preguntas, con el fin de que la búsqueda sea organizada y puntual.

El propósito de esta dinámica es conocer las ideas o concepciones previas de los alumnos y abrir la posibilidad de discusión, la que incidirá sobre las prácticas de lectura en el aula. Asimismo, promover una búsqueda de las distintas nociones de la literatura dadas por teóricos, críticos y escritores, a través del cuestionario; discutirlas en clase, mediante una mesa redonda, y, de esta manera, establecer que la literatura puede verse desde diversas perspectivas: una mirada sociológica, la noción de "institución literaria", los editores, la crítica literaria, entre otras.

Con esta actividad se cumple el primer objetivo específico:

- $\quad$ El estudiante realizará un recorrido por las diversas nociones del concepto de literatura.

Y el primer contenido de la fase:

- Historia de la literatura: orígenes y transformaciones.

- La tercera actividad, que dura 2 lecciones, consiste en pedir a los estudiantes que recopilen en sus casas y traigan al aula diferentes textos. Estos pueden ser literarios, de entretenimiento, educativos, publicitarios, entre otros.

En la clase, los alumnos intercambiarán los textos, los observarán, comentarán y clasificarán como literarios o no literarios, con los literarios, la docente explicará que la literatura posee diversas funciones y que, a través de ella, se pueden entretener, buscar información, conocer otras realidades y ejercitar su sentido crítico.

La docente puede llevar otros textos como ejemplos.

Con esta actividad se cumple el segundo objetivo específico:

- $\quad$ El estudiante inferirá la importancia de la literatura como producción significante estético-ideológica.

$\mathrm{Y}$ el segundo y tercer contenido de la fase. 
- $\quad$ Concepto de texto.

- Funciones de la literatura: estética, de entretenimiento, de conocimiento, social, educativa o pedagógica.

- La cuarta actividad se realizará con el propósito de que los estudiantes conozcan y diferencien las características de la lengua literaria.

Duración: 4 lecciones.

La docente, a través de una clase magistral, explicará las características de la lengua literaria: ficcional, connotativa, plurisignificativa y dialógico-cultural.

Posteriormente, solicitará a los alumnos que elijan un texto literario, el de su gusto. (Caja Viajera). Como trabajo extraclase, lo leerán e identificarán las características. Traerán en una hoja ejemplos del texto en los que se encuentran las características.

Estas hojas se pegarán en un mural o espacio preparado por la docente llamado "Estela literaria", (se entiende por estela, la señal que deja en el agua un barco que navega). Esto con el fin de que los alumnos comprendan que en la literatura no hay nada gratuito sino que todo tiene una razón de ser y el hecho de que él la comprenda, lo ejercita como lector.

En este sitio se expondrán los trabajos y los estudiantes tendrán la oportunidad de apreciarlos.

Con esta actividad se cumple el tercer objetivo específico:

- El estudiante reconocerá la lengua literaria como un sistema ficcional, connotativo, plurisignificativo, $\mathrm{y}$ como una manifestación dialógicocultural.

Y el cuarto contenido de la fase.
- Características de la lengua literaria: ficcional, connotativa, plurisignificativa y dialógico-cultural.

A través del recorrido por esta fase, los estudiantes habrán adquirido un sustento teórico y nociones diferentes de lo que es literatura, lo que les brinda herramientas para fortalecer su posición ante el texto literario. Sin embargo, esta fase no puede resultar exitosa sin la fase que a continuación se presenta, ya que sería inútil que el estudiante domine conceptos teóricos que no podrá aplicar cuando lee, por esta razón, es necesario que adquiera habilidades que le permitan comprender y disfrutar del texto.

\section{Tercera Fase: Adquisición de habilidades de lectura}

A través del estudio que se realizó en el Liceo de Heredia se encontró que, la lectura de textos literarios se orienta en proponer tareas centradas en el texto, como contestar preguntas, hacer un resumen y realizar un examen. En estas tareas, el alumnado repite y parafrasea, de forma parcial o total, los contenidos dados por la profesora y el libro de texto. Esta situación se presenta debido a que la docente considera que sus estudiantes dominan ciertas habilidades al leer, sin embargo, no es así. Al mismo tiempo, la profesora plantea tareas que tienen como finalidad evaluar el resultado de la lectura, o bien, verificar si se ha comprendido el texto, por esta razón, las tareas son un fin en sí mismas y la intención de leer es leer y no interpretar y disfrutar.

En este sentido, no se guía al estudiante al conocimiento sino que ya está determinado y delimitado. Como consecuencia, el estudiante no interactúa sino que se convierte en un receptor pasivo de la literatura en donde el saber está terminado.

En este punto se hace necesario citar lo que plantea Silvia Méndez Anchía en su 
artículo El desarrollo de las pautas emanadas de un documento curricular en dos Libros de Texto (1999), en donde realiza un diferenciación entre lo que respecta a la metodología activa y pasiva:

Metodología activa: (...) se asocia con la promoción del aprendizaje significativo (...) crear la necesidad y el placer de leer, presentando el contacto con el texto de maneras diferentes, en las cuales predomine un afán lúdico, que invite a los estudiantes a explotar los sentidos de los textos; realizar actividades que promuevan la imaginación, el juicio crítico y la actitud creadora, a la vez que permitan efectuar un distanciamiento de la realidad para objetivarla, jerarquizarla y cuestionarla; construir el significado con base en los textos y en su experiencia anterior(...) (Méndez, 1999, p. 241).

Contrario con lo anterior, la metodología pasiva podría considerarse como aquella que:

No cumple con los lineamientos anteriores, es decir, se acerca más a un modelo autoritario, vertical y unidireccional, en donde predomina la directividad que enfatiza en los contenidos (Méndez, 1999, p. 241).

Tomando en cuenta esta diferenciación, los adolescentes no se conciben como sujetos que forman parte de una realidad, no se les impulsa a conocerla ni interpretarla. No se promueve la comprensión, la búsqueda de soluciones alternativas, en donde se pueda seleccionar y evaluar el resultado; al contrario, el ejercicio y el análisis literario es cerrado y limitado. Se demuestra que no hay estimulación del razonamiento ni conexión con la realidad del alumnado.

En este sentido, el libro de texto sigue una pauta directiva: el estudiante responde a una estructura definida de antemano, lo que le impide participar en la construcción del significado de la obra.

Desde esta perspectiva, se concibe el proceso de lectura como unidireccional, es decir, el alumno lee el texto, almacena la información, la memoriza y la repite en un examen. Debido a la situación antes descrita, el propósito de esta fase es que el estudiante adquiera habilidades de lectura mediante un modelo interactivo que permita el contacto con otros contextos comunicativos, en donde el docente pueda intervenir para proporcionar ayudas y mediaciones para que el estudiante aprenda a leer. Asimismo, lo que se busca es que el alumnado, además de leer, logre comprender que la lectura puede potenciar la formulación de hipótesis sobre el contenido, hacer referencias sobre el significado de una palabra y desarrollar sus capacidades como lectores.

\section{Objetivo general}

El estudiante reconocerá el proceso de lectura como una actividad comunicativa y de representación del mundo con el propósito de adquirir y desarrollar sus capacidades como lector.

\section{Objetivos específicos}

El estudiante

1. Empleará algunas técnicas didácticas facilitadas por la docente, para acercarse al texto literario.

2. Desarrollará la capacidad de comprensión lectora en los niveles: literal, reorganización de lo explícito, inferencial, evaluativo, recreativo o aplicativo.

3. Diferenciará textos escritos de carácter expositivo, narrativo, descriptivo o dramático, con el fin de diferenciar los distintos géneros literarios.

\section{Contenidos}

- $\quad$ Niveles de lectura:

- Literal y de organización de lo explícito: reconocimiento de ideas y detalles, secuencias, clasificación de la información, caracterización de personajes, tiempos, lugares. 
- Inferencial o figurativo: interpretación del lenguaje connotativo.

- Apreciativo o evaluativo: afirmación o impugnación de las ideas, comparación del texto con otros textos, evaluación crítica y fundamentada del texto.

- Aplicativo o recreativo: reconstrucción del texto en otros códigos.

\section{Actividades}

Para llevar a cabo esta fase se requiere de una gran motivación por parte de la docente y sus estudiantes, además de la coordinación con el Departamento de Biblioteca de la institución. La docente, en conjunto con la bibliotecaria, revisarán y seleccionarán el material: títulos, cuentos, novelas, entre otros.

Con el propósito de incentivar la lectura, esta fase pretende que los estudiantes desarrollen la capacidad de comprensión lectora y que, al mismo tiempo, puedan disfrutarla.

Asimismo, esta tercera fase puede iniciarse simultáneamente con la segunda fase.

La primera actividad consiste en que el alumnado construya un Diario de Lectura, esta idea fue propuesta por Guillermo Bustos Peraza, (Bustos, 2000). Sin embargo, en esta propuesta se sugieren algunas modificaciones.

Duración: 2 lecciones.

- El diario tendrá el siguiente cuadro, el cual será facilitado por la docente a los alumnos. No obstante, la construcción del diario será exclusiva de los estudiantes y las estudiantes: todos podrán utilizar los materiales de su gusto, así, el diario tendrá su sello personal. Lo anterior, con el fin de que el alumnado construya un espacio propio en el que pueda expresar sus opiniones con respecto a lo que lee.

\begin{tabular}{|c|c|c|c|c|c|c|}
\hline $\begin{array}{c}\text { Día } \\
\text { en que lé́ }\end{array}$ & Fecha & $\begin{array}{c}\text { Minutos u horas } \\
\text { de lectura }\end{array}$ & $\begin{array}{c}\text { Título } \\
\text { del texto }\end{array}$ & $\begin{array}{c}\text { Aspectos } \\
\text { que me } \\
\text { gustaron }\end{array}$ & $\begin{array}{c}\text { Aspectos } \\
\text { que no me } \\
\text { gustaron }\end{array}$ & $\begin{array}{c}\text { Tareas } \\
\text { asignadas } \\
\text { por la profe }\end{array}$ \\
\hline & & & & & & \\
\hline
\end{tabular}

A través de esta actividad se pretende que el alumnado tome conciencia de cuánto tiempo dedica a la lectura, también, que pueda comprender que a través de ella se generan nuevas ideas, pensamientos, conocimientos, realidades y de qué manera, como sujetos sociales, son capaces de mirar $\mathrm{y}$ entender esos nuevos elementos y, sobre todo, que puedan expresar lo que piensan y logren comunicarlo. 
El informe de lectura será entregado a la docente, quien procurará tomar cierto tiempo para que los estudiantes y las estudiantes compartan sus inquietudes y experiencias.

Con esta actividad se cumple el primer objetivo específico:

- $\quad$ El estudiante empleará algunas técnicas didácticas para acercarse al texto literario. Unida a esta actividad surge la siguiente pregunta $\dot{\imath} \boldsymbol{Y} q \boldsymbol{q u e ́}$ libros leeremos?

Con el fin de dar continuidad al diario de lectura, la docente coordinará con el departamento de Biblioteca la iniciativa llamada: La Caja Viajera. Ambas actividades se llevarán a cabo al mismo tiempo.

La Caja Viajera tendrá en su interior libros que, con anterioridad, fueron seleccionados por la docente y las bibliotecólogas. Los textos seleccionados serán de carácter expositivo, narrativo, descriptivo y teatral.

La bibliotecóloga llegará al aula, una vez a la semana, con la Caja Viajera y los estudiantes elegirán el libro que deseen leer. Cada libro tendrá su respectiva boleta de préstamo y deberá ser devuelto a la biblioteca durante la siguiente semana.

Antes de poner en marcha la iniciativa de La Caja Viajera, la docente explicará a los estudiantes la importancia de los niveles de lectura. Esto con la intención de que los alumnos se acerquen al texto literario y comprendan cada nivel y, asimismo, puedan expresar en el diario de lectura sus opiniones. Es decir, el estudiante logrará reconocer ideas, caracterizar personajes, interpretar y opinar con respecto a lo que lee, y compartir su lectura con sus compañeros. De esta forma, explorarán los diferentes niveles de lectura, mediante algunas tareas que la docente asignará para cada nivel.

Las tareas se basarán en ideas del libro de Ducca y Rojas, Despertando a las palabras (1993).
- $\quad$ Para el nivel de lectura literal, la tarea asignada será reconstruir la historia narrada mediante una tira cómica, cada tira se pegará en las paredes del aula. Así cada estudiante puede contar su experiencia.

- $\quad$ Para el nivel de lectura reorganizacional, los estudiantes traerán en el diario de lectura la idea principal y secundarias del texto. Sus ideas se expondrán oralmente.

- $\quad$ Para el nivel de lectura inferencial: la docente asignará algunas preguntas:

1. ¿En qué época ubicaría el texto? ¿Por qué?

2. ¿Cuáles personajes incluiría o cambiaría en el texto?

3. Redacte un final diferente para el texto.

- $\quad$ Para el nivel de lectura evaluativo, los estudiantes buscarán una noticia, reportaje o documental que ejemplifique la realidad del texto.

- $\quad$ Para el nivel de lectura apreciativo, la docente le pedirá a los estudiantes que elijan a un personaje con el que se identificaron o un acontecimiento importante para ellos. Cada estudiante ilustrará en una hoja en blanco, ese acontecimiento o las semejanzas y diferencias con el personaje electo. Las ilustraciones se documentarán en una especie de registro. Éste será consultado por los estudiantes y las estudiantes con el propósito de compartir las diversas lecturas.

- Para el nivel de lectura recreativo, los estudiantes compararán el texto con alguna película, video o canción musical, anuncio publicitario, entre otras. Las comparaciones serán expuestas a los compañeros. 
Con esta actividad se cumplen los objetivos específicos 2 y 3 :

- Desarrollará la capacidad de comprensión lectora en los niveles: literal, reorganización de lo explícito, inferencial, evaluativo, recreativo o aplicativo.

- Diferenciará textos escritos de carácter expositivo, narrativo, descriptivo o dramático, con el fin de diferenciar los distintos géneros literarios.

Y el único contenido: Los niveles de lectura.

En esta fase los estudiantes aprenderán a comprender y compartir con el texto literario. Serán capaces de participar abiertamente en el proceso de lectura, asimismo desarrollarán sus capacidades como lectores y estarán listos para analizar textos.

\section{Cuarta fase: ¿Cómo realizar análisis literario?}

\subsection{Análisis literario según el Ministerio de Educación Pública}

Dentro de los programas de estudio de Español, promovidos por el M.E.P. en el año 2005, para lo estudiantes de secundaria del III ciclo, se plantean cuatro objetivos generales por cumplir con respecto a la enseñanza de la literatura:

1. Desarrollar la capacidad de comprensión lectora en los niveles: literal, reorganización de lo explícito, inferencial, evaluativo, recreativo o aplicativo, utilizando textos literarios.

2. Reconocer el lenguaje literario como un sistema de ficción, connotativo, como una intertextualidad, como una práctica social, como una forma ideológica y una institución.

3. Identificar el predominio de las diversas categorías constitutivas en cada uno de los géneros (lírica, épica, y sus modalidades, drama y ensayo) con el fin de obtener una visión global de las regulaciones que han orientado la lectura y la escritura de lo literario.

4. Comprender la importancia del ordenamiento historiográfico literario (Romanticismo, Realismo, Naturalismo y Modernismo) como un recurso que permite obtener una visión global de la cultura y, en particular, de la evolución de la literatura latinoamericana.

5. Comprender que la lectura de todo texto y del literario en particular, implica una competencia del lector como sujeto participante, para enriquecer su actividad de percepción y de desciframiento (M.E.P., 2005, p. 25).

Asimismo, en el texto La palabra al margen, de Mora (1986) se plantean los siguientes objetivos propuestos por el M.E.P. en el año 1986:

1. Partiendo de algunos conocimientos, el alumno comentará obras literarias. Partiendo de los conocimientos y experiencias que posee, el alumno creará, empleando el idioma, obras nuevas.

2. El estudiante, conocerá en -forma elemental- algunos principios de estilo y análisis literario, para conocer lo creado por escritores connotados o bien para emplearlos en obras que él mismo hace.

3. Organizará lo que debe leer, hablar, escribir o escuchar.

4. Reconocerá figuras y géneros literarios fundamentales.

5. Reconocerá las partes del libro.

6. Leerá a la velocidad de 180 palabras por minuto, con un 70 por ciento de comprensión como mínimo" (Mora, 1986, p. 88).

Como puede apreciarse, si bien han existido cambios con respecto a los objetivos propuestos en los programas de estudio del Español del año 1986 al año 2005, podrá visualizarse, también, con la revisión que a continuación se realizará, que los cambios se han dado en la forma (redacción de los objetivos) pero no en la práctica al enseñar la literatura. 
Visto a la luz de lo anterior, respecto a la manera en que el M.E.P. plantea estos objetivos, Mora (1986), en el libro La palabra al Margen, la enseñanza del español en crisis señala que existe un desfase entre la teoría (elementos de estilística) y lo que podría ser la práctica (análisis de las obras), es decir, para esta autora la discordancia entre lo que se plantea y lo que se practica en el salón de clase para enseñar el análisis de textos literarios va más allá y toca los contenidos y la didáctica aplicada para enseñar el español, en este sentido expresa:

Dentro de un mismo esquema, el alumno repite iguales tareas, desarrolla idénticas destrezas y se enfrenta a problemas estructuralmente idénticos. Lo que varía es el contenido que se utiliza, lo cual afirma la inexistencia de un proceso dinámico y paulatino de enseñanza en sentido estricto (Mora, 1986, p. 38).

Tomando en cuenta este criterio, se deduce que la idea esencial de los objetivos planteados por parte del M.E.P. en el año 1986 no se cumple debido a que el estudiante, en la realidad, no es ese lector participante y dinámico, tampoco obtiene una visión tan global de su contexto porque sigue un patrón de aprendizaje ya establecido.

Asimismo, en los programas de estudio del español propuestos por el M.E.P en el año 2005 para analizar los textos literarios, se encuentra que los objetivos y contenidos se contradicen; mientras el objetivo plantea reconocer la lengua literaria como un sistema ficcional, connotativo, plurisignificativo y dialógico cultural, en los contenidos se presenta un listado de conceptos que el estudiante debe conocer y que dejan a un lado la importancia de identificar los diversos significados del texto así como su inserción en un momento particular de la historia y la cultura.

En este sentido, el objetivo planteado por el programa para analizar el texto literario como un sistema plurisignificativo, no posee una continuidad o conexión con los contenidos sino que se solicita al estudiante analizar: narrador, tipos (omnisciente, testigo, protagonista), organización secuencial de la historia narrada, código apreciativo, tiempo, mundo mostrado, personajes etc. (MEP, 2005 , p. 32). Lo que provoca una anulación del objetivo deseado y, la no experiencia del estudiante ante la diversidad del texto literario, en donde la ficción y la realidad muestran su complejidad y riqueza.

De esta manera, los contenidos de literatura se reducen a caracterizar los géneros literarios y estudiar las figuras retóricas, así lo señaló Mora (1986), al afirmar que en ese entonces, se olvidó el avance de la historia literaria contemporánea, la que cuestionó y superó la sucesión cronológica de autores y períodos.

En esta línea de pensamiento, el programa del Tercer Ciclo, planteado para el 2005 , tampoco incluye contenidos de literatura que orienten el acercamiento del estudiante a los textos literarios; el resultado, es la fragmentación y la simplificación de lo literario, ya que en el caso de los estudios sobre la literatura, los programas no reflejan la discusión de la naturaleza y función del texto literario.

Según Mora (1986), lo anterior tiene efectos inevitables sobre el análisis textual que resulta empobrecido y limitado al reconocimiento de algunas figuras. En este sentido afirma que:

(...) la literatura en tanto práctica discursiva específica, se considera parte de la producción cultural de las distintas formaciones sociales, y por ello se afirma que se trata de una noción claramente histórica, inserta en el conjunto de la actividad humana como un todo (Mora, 1986, p. 33).

Es por ello que en los objetivos de los programas de estudio del Español se evidencia que la literatura es planteada como un producto cultural, sin embargo, en los contenidos no es planteada como tal. En palabras de Mora, la literatura

Resulta ser un campo aislado, ahistórico, vaciado de toda significación humana. De ahí que los conceptos que orientan el estudio de la literatura propicien una visión ahistórica, estática y fragmentaria del objeto. Esta manera de acercarse a la literatura no sólo la 
reduce claramente, sino que desaprovecha elementos imprescindibles para el disfrute y la verdadera comprensión de este quehacer y sus productos (Mora, 1986, p. 34).

Los elementos expuestos anteriormente confirman la idea de Mora (1986) al señalar que el estudio de la literatura sufre una creciente simplificación al aplicarse en la educación secundaria. Se rechaza la teoría y la interpretación; el análisis literario se reduce a la descripción de algunos rasgos de "estilo", entendidos en forma desarticulada y desvinculados de la significación profunda de los textos.

Si se toman algunos de los objetivos propuestos por los programas de Español del año 2005, en el área de literatura, junto a sus respectivos contenidos, se encuentra que si la lectura se hace solo desde los contenidos, sin tomar en cuenta los objetivos, se pierde la parte interpretativa e histórica que se intenta promover en el objetivo. Aunque el objetivo se centra en mostrar la importancia del contexto socio-histórico en el cual se sitúa el texto, el contenido queda desprovisto y se centra en dar conceptos terminados acerca de los elementos que componen un análisis literario.

\section{El propósito}

El estudio realizado demostró que la literatura es concebida como expresión de un sujeto personal (el autor), privada de su relación con el contexto, porque éste aparece como mero fondo en el que los hechos literarios ocurren sin vínculos, la literatura entonces pierde su carácter social y su historia se vuelve una línea de tiempo. En este sentido, la literatura se enseña para ser evaluada en un examen y su historia se reduce a una cronología de eventos en donde el texto literario queda desprovisto de toda intencionalidad e interpretación.

Es así como se desarrolla un modo de leer hegemónico con el que se abordan, prácticamente, la totalidad de los textos literarios, es decir, todo se lee de la misma manera: el modo de leer es unívoco. Esto genera que la literatura sea entendida como un reflejo de lo real, que el texto no se lea en correlación con un contexto; que el autor sobresalga aislado del contexto y que la obra literaria represente una lectura intuitiva y personal, en donde se cumplan las obligaciones establecidas por el programa de estudios de Español. Debido a esta situación, el propósito de esta fase es crear métodos y estrategias alternativas para enseñar a los estudiantes cómo realizar análisis literario.

Es importante señalar que el análisis de textos literarios no es solamente realizar un ejercicio de gramática ni de vocabulario ni un comentario moral: en él intervienen elementos indispensables para comprender el texto. Por ejemplo, los estudiantes comprenderán que, en la medida en que los textos literarios están presentes en la vida cotidiana de la sociedad a la que pertenecen, lo importante será mejorar sus capacidades de interpretación de las formas y los mensajes literarios.

Desde este punto de vista, la competencia literaria del alumnado no tendría que ver tanto con el aprendizaje de categorías de análisis insignificantes, sino con el interés que emana del contraste entre sus experiencias personales y las que logrará adquirir a través de la lectura de los textos.

De esta manera, esta fase posee un primer planeamiento en el cual los estudiantes conocerán cómo realizar un análisis literario; distinguirá los rasgos de los diferentes géneros y movimientos literarios, además de las características del discurso literario y la función social que desempeña. Posteriormente, en el artículo Propuesta para analizar el cuento El gato negro de Edgar Allan Poe, La novela Marianela de Benito Pérez Galdós y las Rimas de Gustavo Adolfo Bécquer (Ramírez, 2007), se proponen tres planeamientos diferentes para abordar cada género literario: poesía, cuento y novela. 


\section{Objetivo general}

El estudiante reconocerá que, a través del análisis de textos literarios, puede desarrollar sus habilidades interpretativas, sus capacidades de previsión, de formulación de inferencias, de comparación, de generalización y de valoración con el propósito de disfrutar de la lectura.

\section{Objetivos específicos}

El estudiante:

1. Comprenderá en qué consiste realizar el análisis literario de un texto con el propósito de explorar sus múltiples sentidos.

2. Distinguirá los rasgos propios de los diferentes géneros literarios: Narrativa y Poesía.

3. Reconocerá la función de los componentes de la narrativa.

4. Distinguirá los rasgos propios de los movimientos y géneros literarios: leyenda, cuento, poesía, novela, crónica, romanticismo, realismo, naturalismo y modernismo como funciones convencionales del lenguaje.

\section{Contenidos}

1. El ciclo de la comunicación literaria: autor, lector, texto, contexto.

2. La crítica literaria como una actividad de exploración de los múltiples sentidos del texto.

3. Pasos para analizar el texto literario.

4. Géneros literarios: orígenes y modalidades: épica (narrativa), lírica (poesía).

5. Género narrativo: leyenda, novela, cuento, crónica.

6. Componentes de la narrativa: narrador, organización secuencial de la historia, código apreciativo, registro del habla, uso del diálogo, espacios, personajes y relación del texto con el contexto.

7. Movimientos literarios: orígenes y características del romanticismo, realismo, naturalismo, modernismo.

\section{Actividades}

Para abordar los objetivos específicos 1,2 y 3 , y los contenidos $1,2,3$ y 6 se realizarán las siguientes actividades:

- La docente solicitará a sus estudiantes que se reúnan en subgrupos de cuatro integrantes. A cada subgrupo se le entregará un sobre con las siguientes preguntas:

1. ¿Con sus propias palabras podrían definir qué es un texto?

2. ¿Qué creen ustedes qué es un lector?

3. ¿Alguna vez han leído un cuento? ¿Cuál?

4. ¿Cómo saben que un cuento es un cuento?

5. ¿Saben qué es un narrador?

6. ¿Saben quién es un autor?

7. ¿Alguna vez han leído una novela? ¿Cuál?

8. ¿Podrían definir qué es una poesía?

9. ¿Saben qué es realizar un análisis literario de un texto?

10. ¿Conocen algunos pasos para realizar análisis literario?

11. ¿Han escuchado alguna vez la definición del término: crítica literaria?

12. ¿Definan qué es un género literario?

13. ¿Definan qué es un movimiento literario?

- Los estudiantes discutirán sus ideas, unificarán criterios y responderán 
las preguntas. Posteriormente escribirán sus respuestas en una hoja de papel.

- Las respuestas serán leídas en voz alta por un miembro del grupo al que se haya nombrado como vocero.

- $\quad$ Seguidamente el grupo procederá a pegar la hoja en el Árbol de las ideas.

- $\quad$ Este árbol será confeccionado por la docente, y en él cada grupo expondrá sus ideas.

- La docente partirá de estas opiniones y explicará los contenidos correspondientes.

Para abordar el objetivo específico número cuatro:

- Distinguir los rasgos propios de los movimientos y géneros literarios: leyenda, cuento, poesía, novela, crónica, romanticismo, realismo, naturalismo y modernismo como funciones convencionales del lenguaje.

Y los contenidos 4, 5 y 7

Géneros literarios: orígenes y modalidades: épica (narrativa), lírica (poesía).

Género narrativo: leyenda, novela, cuento, crónica.

Movimientos literarios: orígenes y características del romanticismo, realismo, naturalismo, modernismo. dades:

Se realizarán las siguientes activi-

- Los estudiantes investigarán sobre los distintos movimientos literarios.

- Esta actividad, la realizarán en subgrupos de cuatro miembros.
Se le asignará un movimiento literario a cada subgrupo, para que explore su origen, sus ideas y características.

- Cada subgrupo deberá exponer ante la clase los elementos solicitados sobre el movimiento literario respectivo.

- $\quad$ Para exponer la teoría de cada movimiento, la docente llevará pinturas alusivas a estos movimientos y explicará sus características literarias.

Con respecto a los géneros literarios, se llevará a cabo la siguiente dinámica:

- La docente llevará un CD con grabaciones de distintos géneros musicales: salsa, rock, regeetón, metal, ska, celta, entre otros, (los que la docente considere que les interesa a sus estudiantes). Solicitará a los alumnos, que identifiquen los géneros musicales y que escriban los nombres en una hoja en blanco.

- $\quad$ Posteriormente, la docente explicará que la literatura, al igual que la música, se expresa a través de diversos géneros.

- De esta manera, repartirá a los estudiantes fragmentos de cuentos, leyendas, crónicas, poesías y novelas. Cada estudiante intentará descubrir a qué género literario pertenece.

- Las características de cada género estarán pegadas en una de las paredes del aula. De esta forma el estudiante deberá buscar qué características concuerdan con su fragmento.

A través del desarrollo de las fases anteriores, los estudiantes han adquirido herramientas para enfrentarse a un texto literario: han comprendido el objeto de estudio, poseen 
sustento teórico, han adquirido habilidades como lectores y finalmente son capaces de analizar un texto y disfrutarlo. En esta línea, la propuesta lo que busca es una secuencia que facilite la enseñanza de la literatura, tomando en cuenta al alumnado como protagonista del proceso, a los docentes como dinamizadores y facilitadores de conocimientos y también saber explotar y poner en marcha los recursos de cada institución educativa.

\section{Conclusiones}

- A través de estrategias metodológicas creativas e innovadoras, los docentes deben fomentar en los estudiantes hábitos de lectura y actitudes de aprecio por las obras literarias y el uso creativo del lenguaje. Así, contribuir a la adquisición de las habilidades interpretativas.

- $\quad$ El educador necesita diseñar estrategias para comentar textos literarios en clase con una pauta de análisis que les permita a los alumnos profundizar en las formas literarias porque, sólo de esta manera, pueden comprender el texto y, por tanto, apreciar la literatura. Asimismo, disponer de una biblioteca de aula, con los textos que ellos deseen leer.

- Es indispensable favorecer en las aulas la experiencia de la comunicación literaria ya que los alumnos avanzarán en su competencia literaria en la medida en que entiendan que los textos literarios están presentes en la vida cotidiana de nuestras sociedades. Es decir, que entiendan la literatura no sólo como una experiencia estética de carácter personal sino también como un tipo específico de comunicación que tiene lugar en determinados contextos.
- Conjugar la lectura individual de los textos literarios con la búsqueda compartida del significado. Es decir, fomentar estrategias que favorezcan el comentario público de los textos literarios en el aula, la discusión entre compañeros y compañeras, la información del profesor y las referencias a otras obras ya leídas por unos y otras, permiten construir, de una manera cooperativa, una interpretación colectiva de los textos que no anula la apreciación personal sino que la enriquece.

- El docente debe operar en el diseño de su tarea no como un transmisor sino como quien estudia, selecciona y organiza, en perspectiva histórica, el material literario en función de sus alumnos.

- El docente necesita apropiarse de estrategias metodológicas específicas que le faciliten entrenar al alumno en acciones mentales que le permitan elaborar inferencias adecuadas a partir de la información textual y de sus conocimientos previos.

- La selección de textos literarios debe efectuarse con criterios pedagógicos partiendo del horizonte de expectativas de los adolescentes y de sus competencias y hábitos culturales, con el fin de hacer posible que, de una manera gradual, entren en contacto con otros textos literarios de una mayor complejidad.

- Solamente a partir del conocimiento de la realidad de las aulas a través de diagnósticos regulares y estructurados de un grupo de especialistas, podrán derivarse planes y estrategias, opciones metodológicas y formas de actuar que ayuden a transformar la realidad en el sentido deseado. 
- $\quad$ En pleno siglo XXI es necesario llevar a la acción una escuela renovada que trascienda la instrucción formal y transmisiva, que huya de la fragmentación y la parcelación artificiales del currículo, que abandone las prácticas coercitivas y selectivas de evaluación, que se aleje de las prácticas rutinarias para el aprendizaje, y que atienda a la dinámica real de lo que nos circunda, para fomentar el desarrollo autónomo y la creatividad de la colectividad y que de este modo, pueda construir un ambiente integrador y significativo que aumente la comprensión de lo que está ocurriendo en una sociedad cada vez más globalizada.

Las instituciones educativas deben promover situaciones donde la lengua escrita esté arropada por su verdadera función social y cultural, y que impulse la participación de los estudiantes en actos sociales de lectura que tengan propósitos explícitos.

- $\quad$ Es necesaria la creación de una cultura de colaboración y capacitación en la que se ofrezcan a los profesores nuevas iniciativas, nuevos papeles y mayor autonomía. Las capacitaciones deben impartirse atendiendo sus verdaderas necesidades e inquietudes. El discurso de éstas debe ser accesible y sobre todo aplicable a la realidad de aula.

En este sentido se debe priorizar la capacitación a grupos de docentes como una tarea continua y actualizada.

- $\quad$ Para que fructifiquen las propuestas es fundamental llevar a cabo un trabajo sistemático apoyado en la formación del profesorado y en materiales consistentes. Es necesario documentar y difundir las prácticas docentes en este nivel educativo, prestando especial atención a qué hacen los profesores con la lectura, la escritura y el estudio de los alumnos, ya que se trata de saberes que no pueden darse por sabidos, sino que hay que impulsar.

- En la formación del profesorado no solo debe existir un formación inicial sino también una formación permanente. La formación inicial es el conjunto de conocimientos adquiridos durante el estudio de la carrera universitaria, y la formación permanente camina junto a estos conocimientos, el desarrollo curricular, la innovación didáctica y la investigación educativa. Es decir, la formación permanente deberá basarse en la actividad de investigación, con un matiz pedagógico, para que los docentes puedan realizar de verdad la labor de mediadores.

\section{Referencias bibliográficas}

Aguas-Vivas, C. y Madalena, J. I. (2003). Hacer cosas con la lectura. Textos de didáctica de la lengua y de la literatura, 33(1): 34-42.

Aguiar e Silva, V. M. (de) (1968). Teoría de la Literatura, Madrid: Editorial Gredos.

Amoretti H., M. (1992). Diccionario de términos Asociados en Teoría literaria. San José: Editorial Universidad de Costa Rica.

Ausubel, N. H. (1983). Psicología educativa: Un punto de vista cognoscitivo $\left(2^{\mathrm{a}}\right.$ ed.). México: Editorial Trillas.

Bustos P., G. (2000). Vamos a leer. Cuaderno pedagógico de español II para Noveno. Ministerio de Educación Pública. San José: Centro Nacional de Didáctica.

Carvajal, F. y Ramos, J. (2003). Leer, comprender e interpretar en un aula que investiga. Textos de didáctica de la lengua y de la literatura. 33(1), 11-23. 
Colomer, T. (1995). La adquisición de la competencia literaria. Textos de didáctica de la lengua y de la literatura, 4, 8-22.

Ducca, I. y Rojas, M. (1993). Despertando a las palabras (Cuarto). San José: Editorial Costa Rica.

Ducca, I. y Rojas, M. (1993). Despertando a las palabras (Quinto). San José: Editorial Costa Rica.

Ducca, I. y Rojas, M. (1993). Despertando a las palabras (Sexto). San José: Editorial Costa Rica.

Frases de Aristóteles. (s.f.). Extraído el 16 de setiembre de 2005 desde http:// www.scrib/.com/doc/21986/Frasesde-Aristóteles

Kayser, W. (1976). Interpretación y Análisis de la Obra literaria. Madrid: Editorial Gredos.

Lázaro C., F. (1974). Diccionario de términos filológicos ( $2^{\mathrm{a}}$ ed.). Madrid: Editorial Gredos.

Lomas, C. (1999). Como enseñar a hacer cosas con las palabras. Volumen I. España: Editorial Paidós.

López C., M. (2005). Enseñar literatura: fundamentos teóricos. Propuesta didáctica. Buenos Aires: Editorial Manantial.

Méndez, S. (1999). El desarrollo de las pautas emanadas de un documento curricular en dos libros de texto. Revista Educación, 2(23), 237-249.

Méndez, S. (2000). La mediación docente en la comprensión de lectura de textos literarios. Revista Educación, 1(24), 89-105.
Mignolo, W. (1978). Elementos para una teoría del texto literario. Barcelona: Editorial Crítica.

Ministerio de Educación Pública. (2005). Plan de estudio de Español. MEP, San José.

Mora, S. M. (1986). La palabra al margen: la enseñanza del español en crisis. San José: Editorial Nueva Década.

Morales C, E. M. (2002). Leer y pensar 7: antología literaria. San José: Editorial Santillana.

Núñez, M. P. (2003). La formación del profesorado de lengua y literatura: el difícil camino de la innovación. Textos de didáctica de la lengua y de la literatura, 33(1): 79-103.

Palacios L., V. M. y Picado, J. M. (2004). Metodología alternativa para analizar el texto El Ingenioso Hidalgo Don Quijote de la Mancha en $10^{\circ}$ año de la Educación Diversificada. Tesis de Licenciatura: Universidad de Costa Rica, Costa Rica.

Picado G., M. (1983). Literatura Ideología Crítica. San José: Editorial Costa Rica.

Ramírez M., C. (2007). Estrategias metodológicas utilizadas por las docentes de sétimo año en la enseñanza del análisis de textos literarios en el Liceo de Heredia. Tesis de Licenciatura: Universidad de Costa Rica, Costa Rica.

Rojas P., M. y otros. (1996). Español 7: guía didáctica. Serie: Hacia el siglo XXI. San José: Editorial Universidad de Costa Rica: PROMECE, Ministerio de Educación Pública.

Rojas P., M. y otros. (1996). Español 7: texto. Serie: Hacia el siglo XXI. San José: 
Editorial Universidad de Costa Rica: PROMECE, Ministerio de Educación Pública.

Ruiz B., U. y Lomas, C. (2003). Leer y entender. Textos de didáctica de la lengua y de la literatura, 33(1): 7-10.

Sánchez L., C. (2005). ¿Porqué los jóvenes leen mal? Extraído el 16 Septiembre de 2005 desde

http://matosas.typepad.com/ libros/2005/05/porqu_los_jvene.html

Solano, M. R. (2000). El proceso de enseñanza-aprendizaje de la lectura. Revista Educación, 2(24), 151-156.
Trevor H., C. (1999). Enseñanza de la comprensión lectora. Madrid: Editorial Morata.

Varela B., M. (2001). Español $7^{\circ}$ año. Heredia: Editorial Marwal de Heredia.

Vargas, L., Bustillos, G. y Marfán, M. (1984). Técnicas participativas para la educación popular. San José: Alforja.

Vindas, M. y Alvarado, S. (1999). Un cambio de paradigma en la enseñanza de la lectura y la escritura. San José: Editorial Costa Rica. 

ANEXOS 



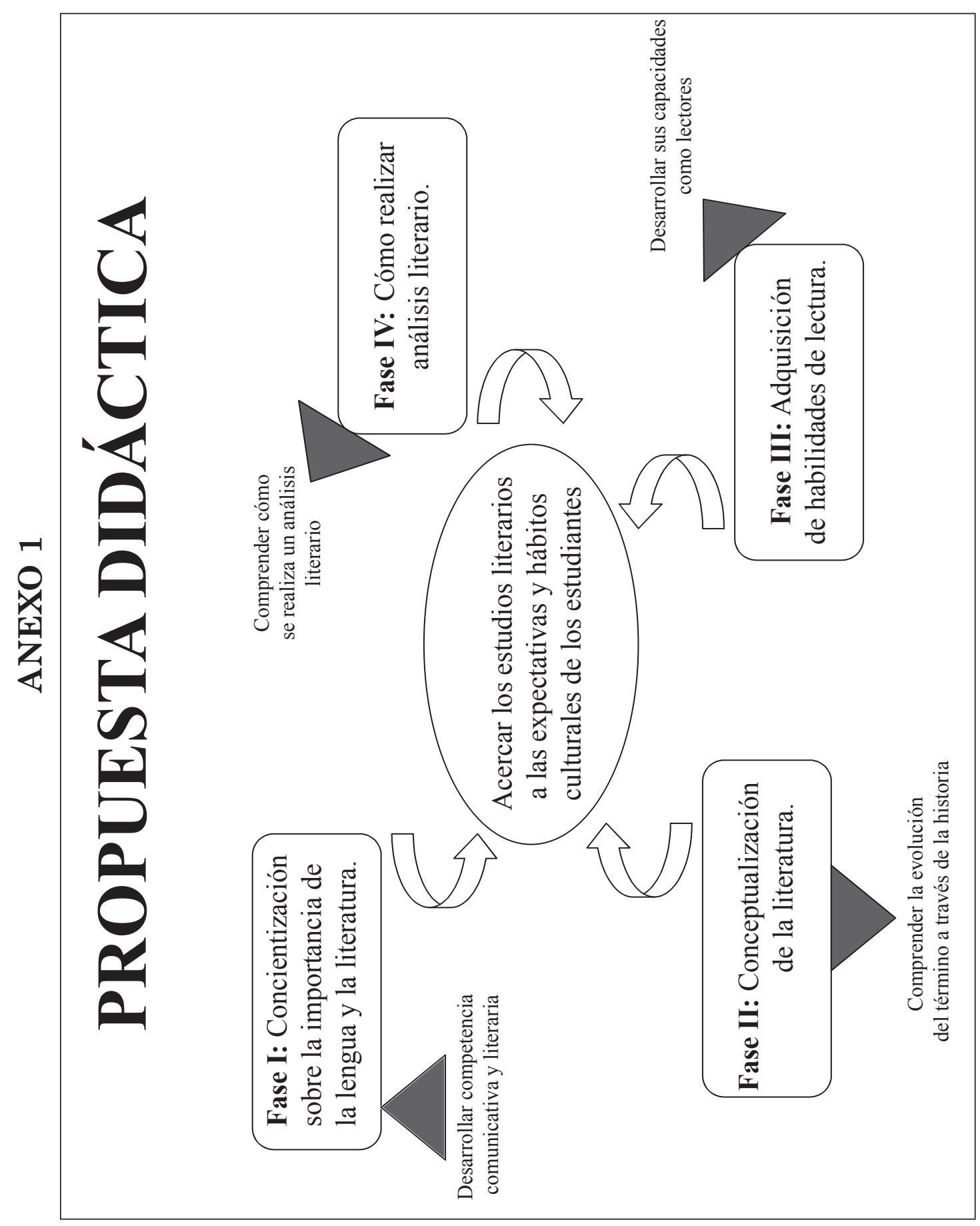




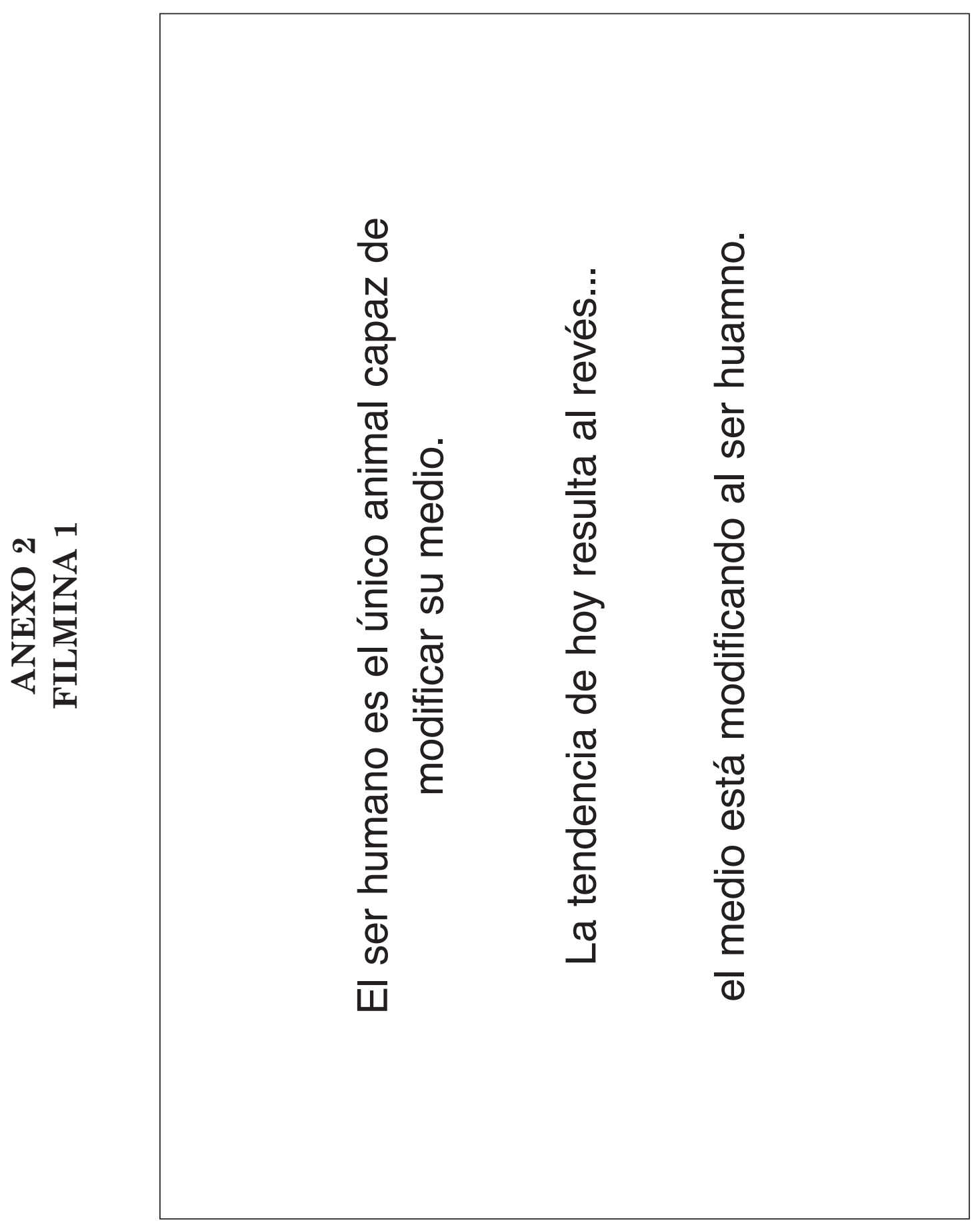




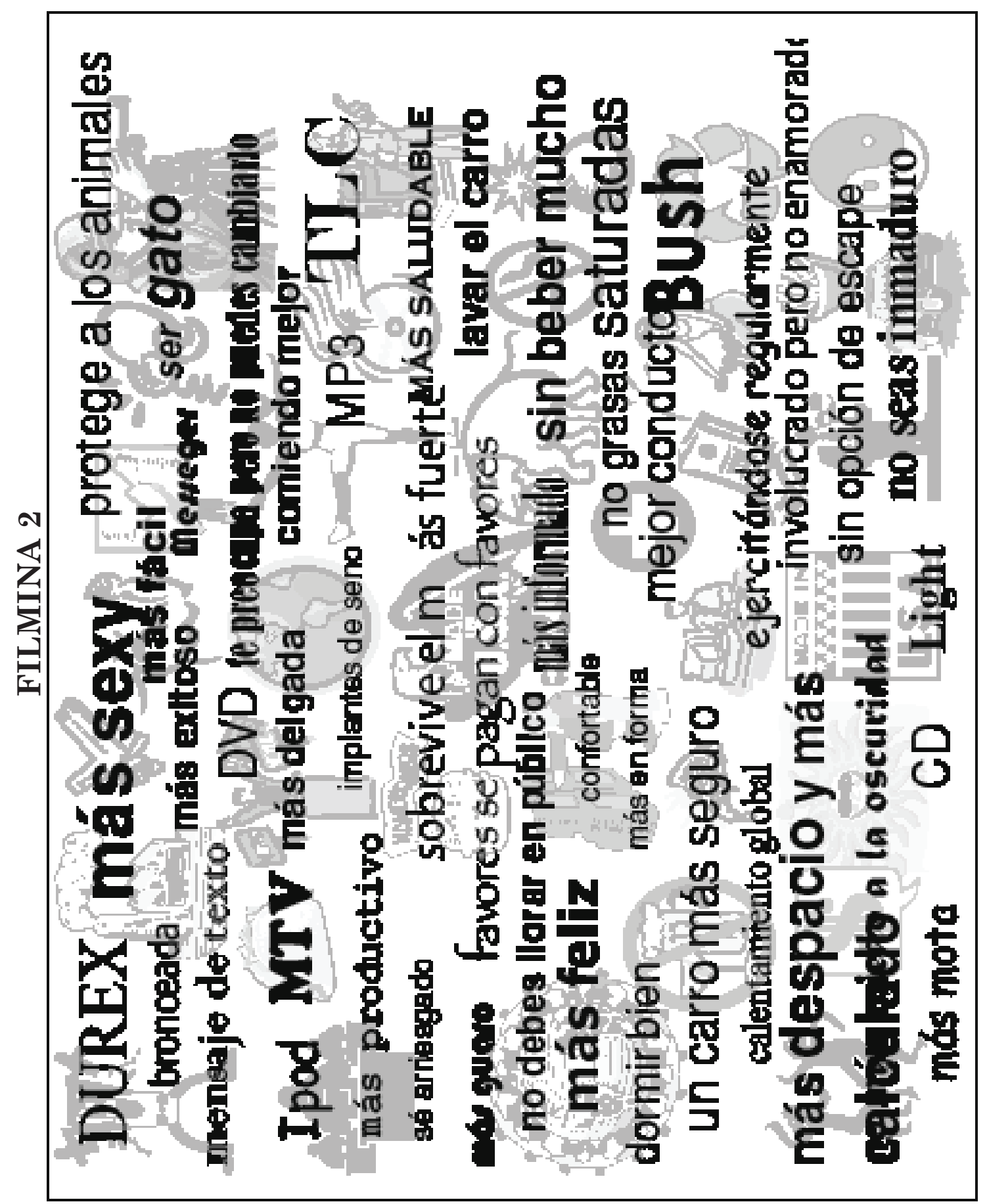




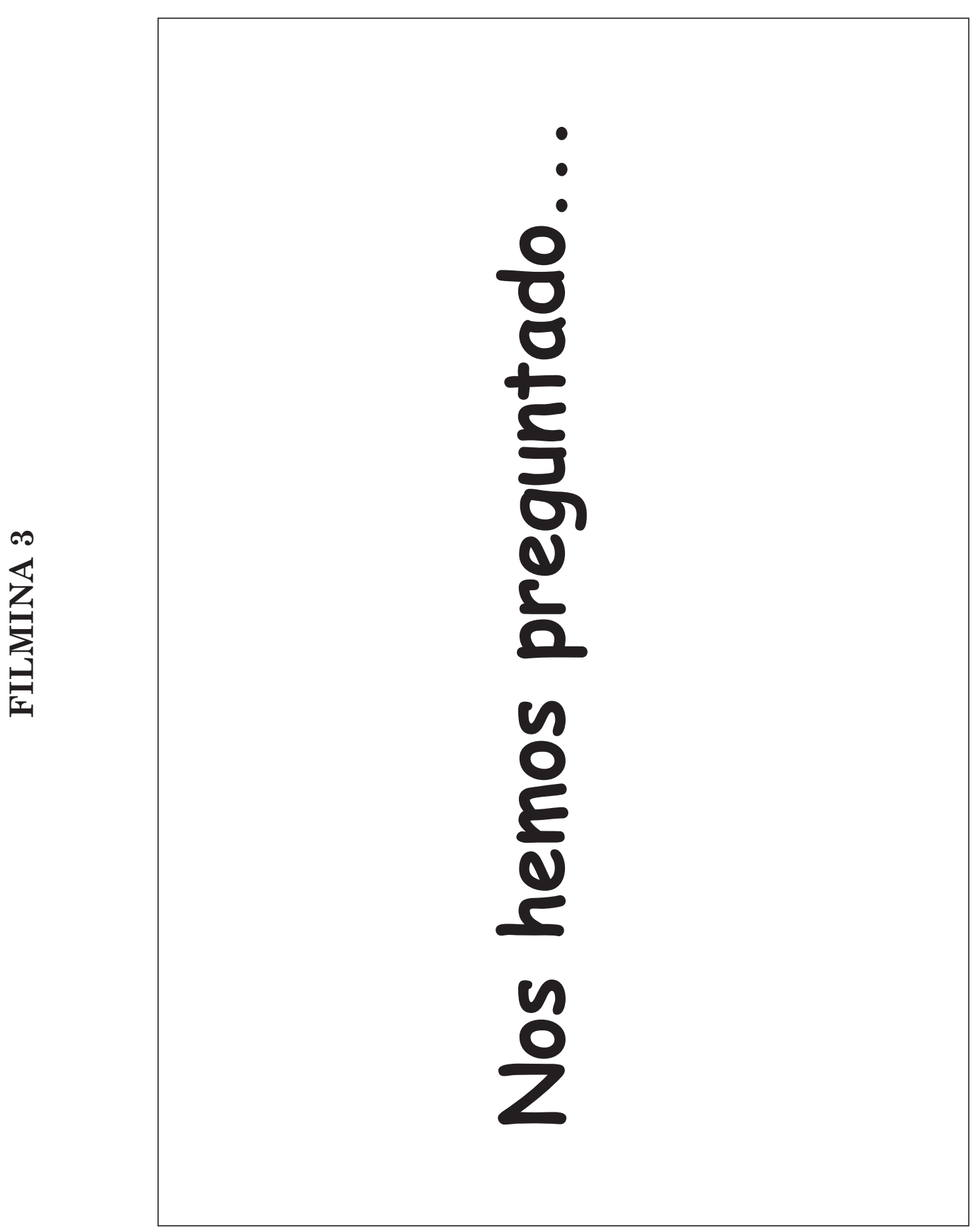


岁

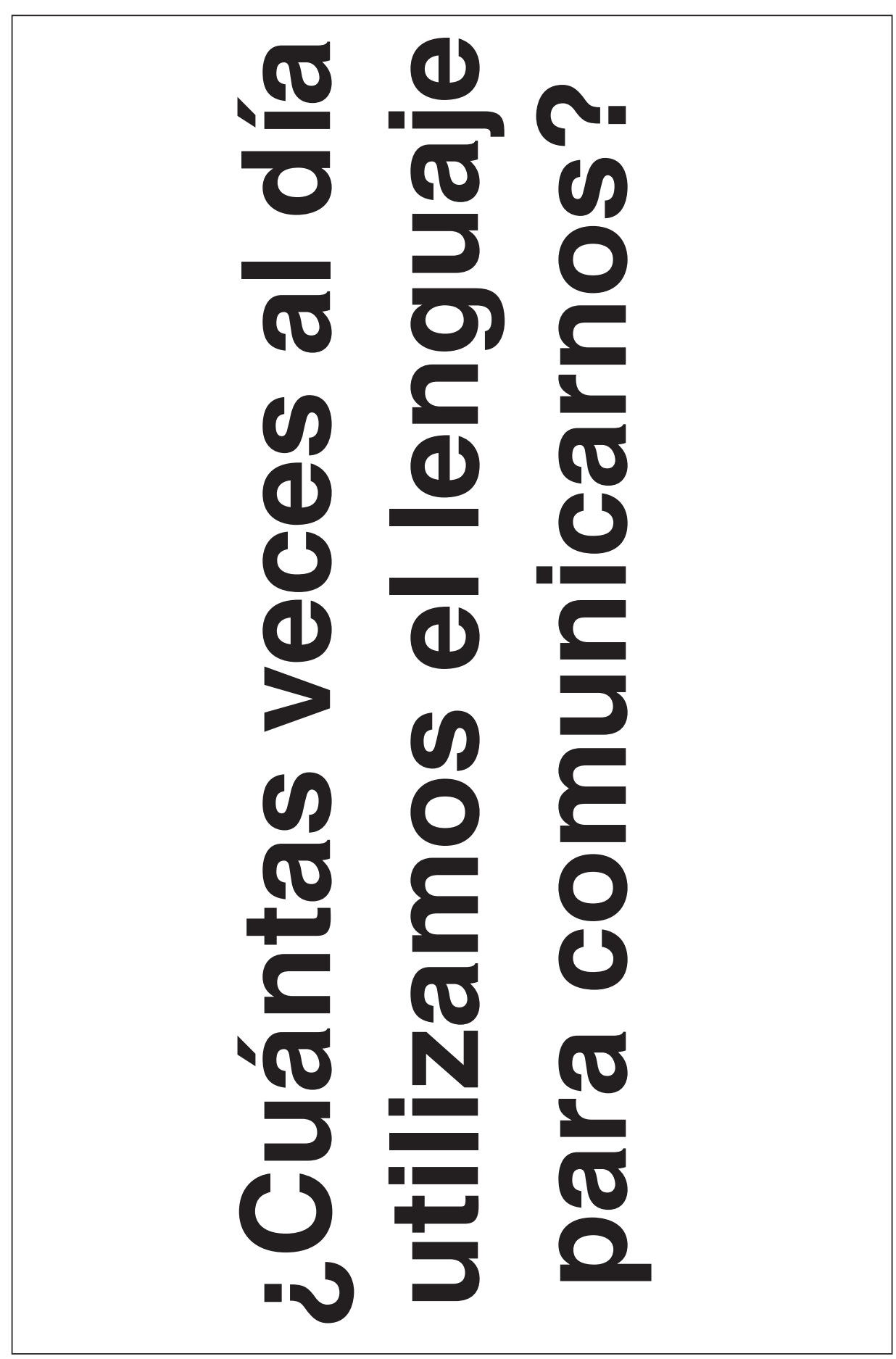




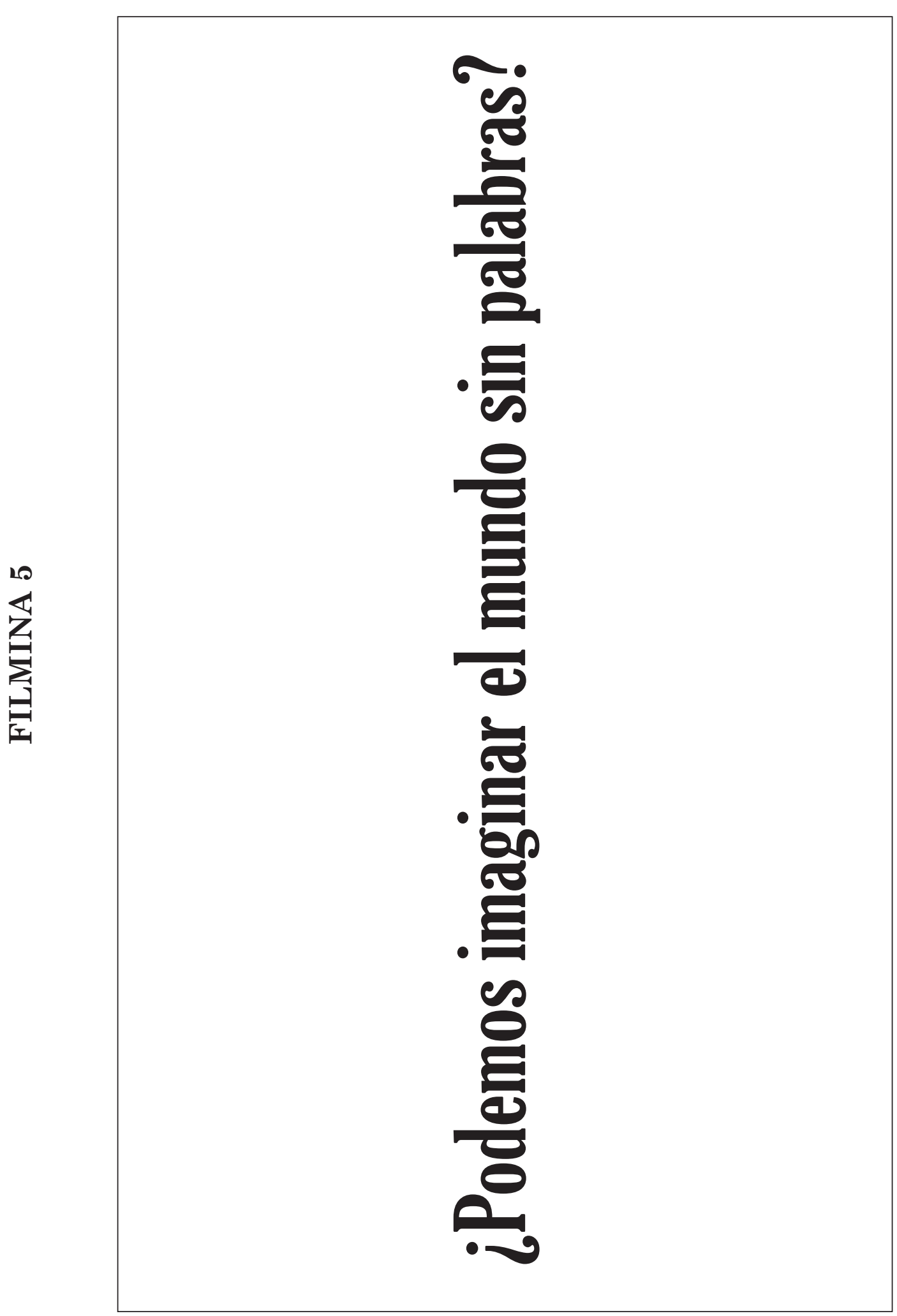




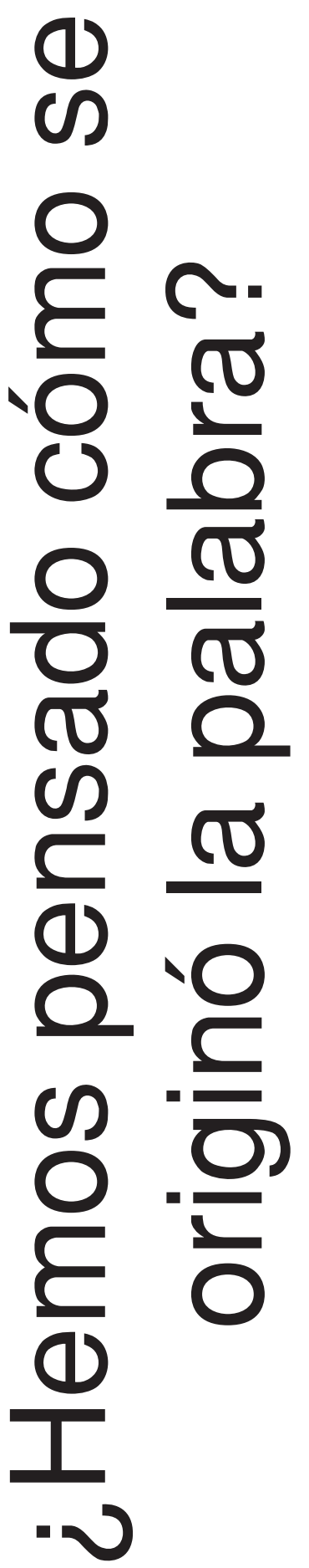




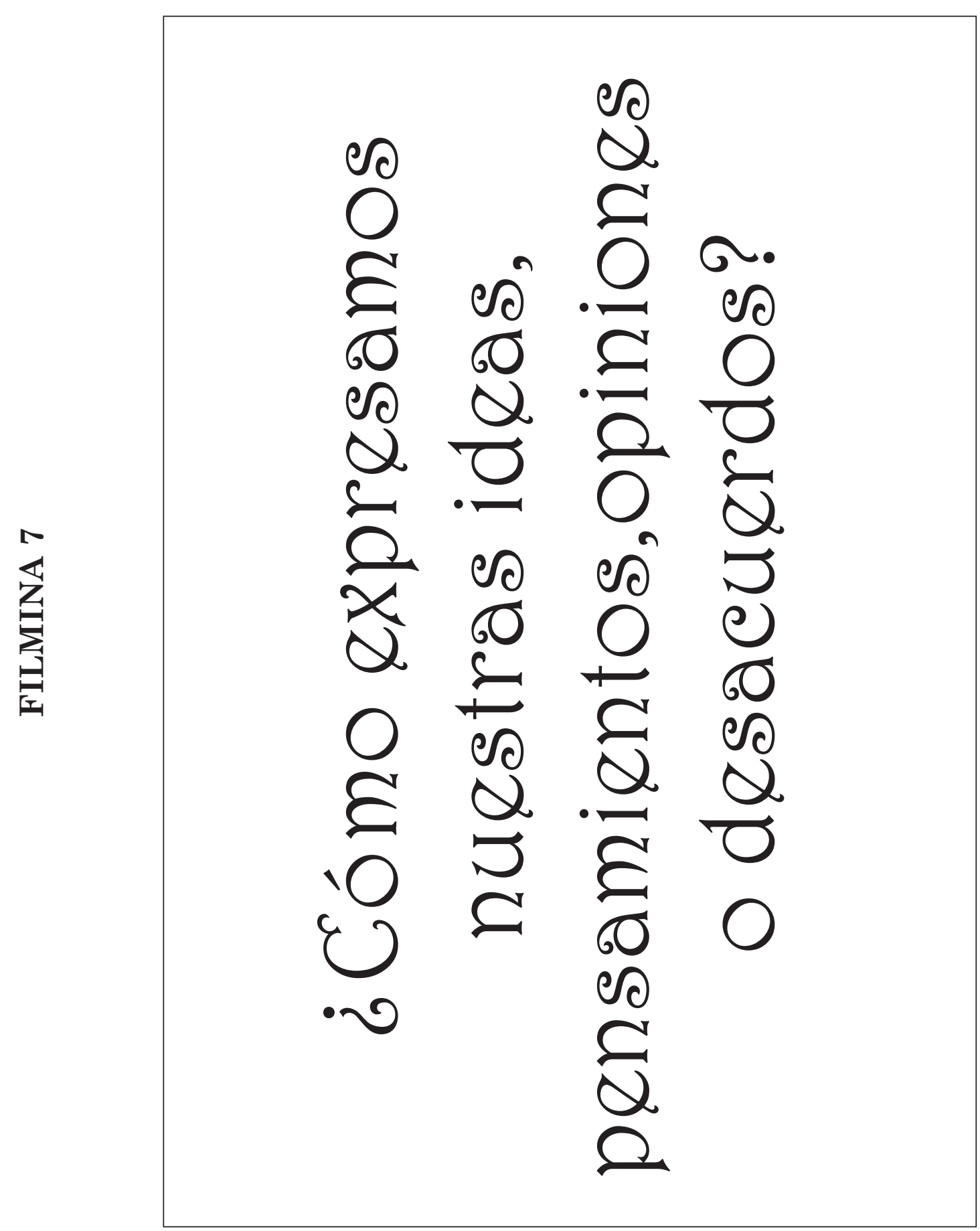




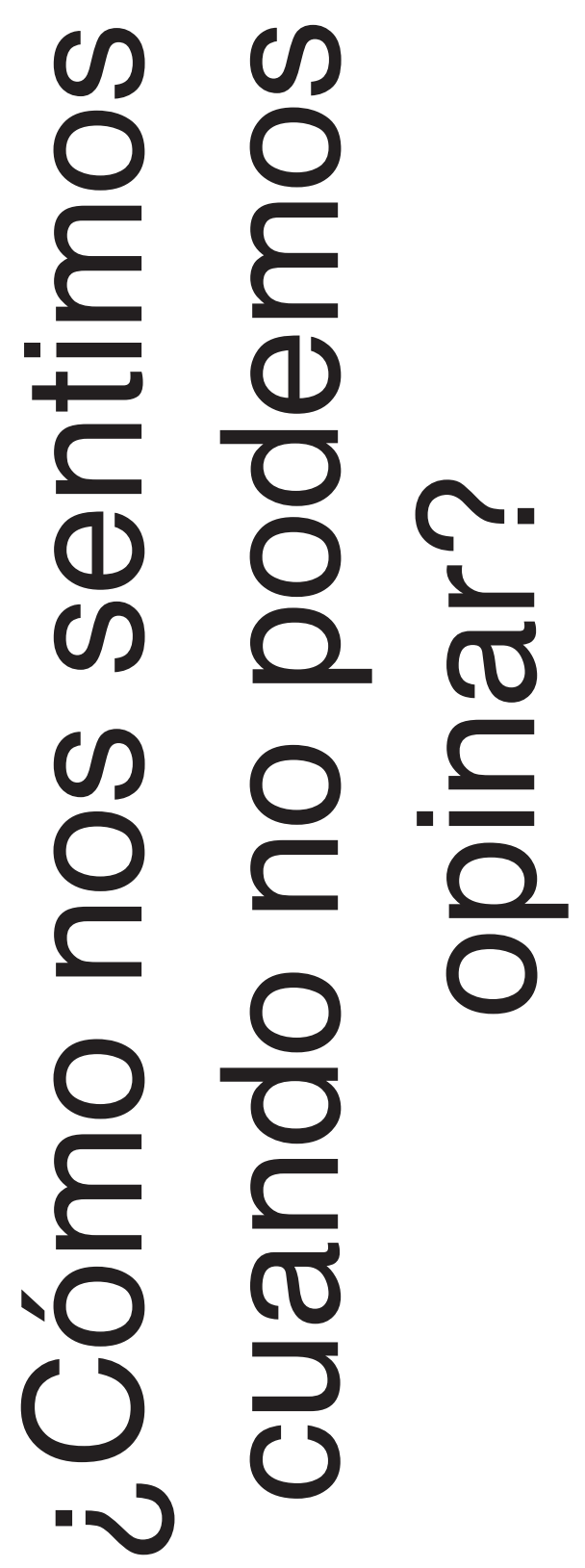




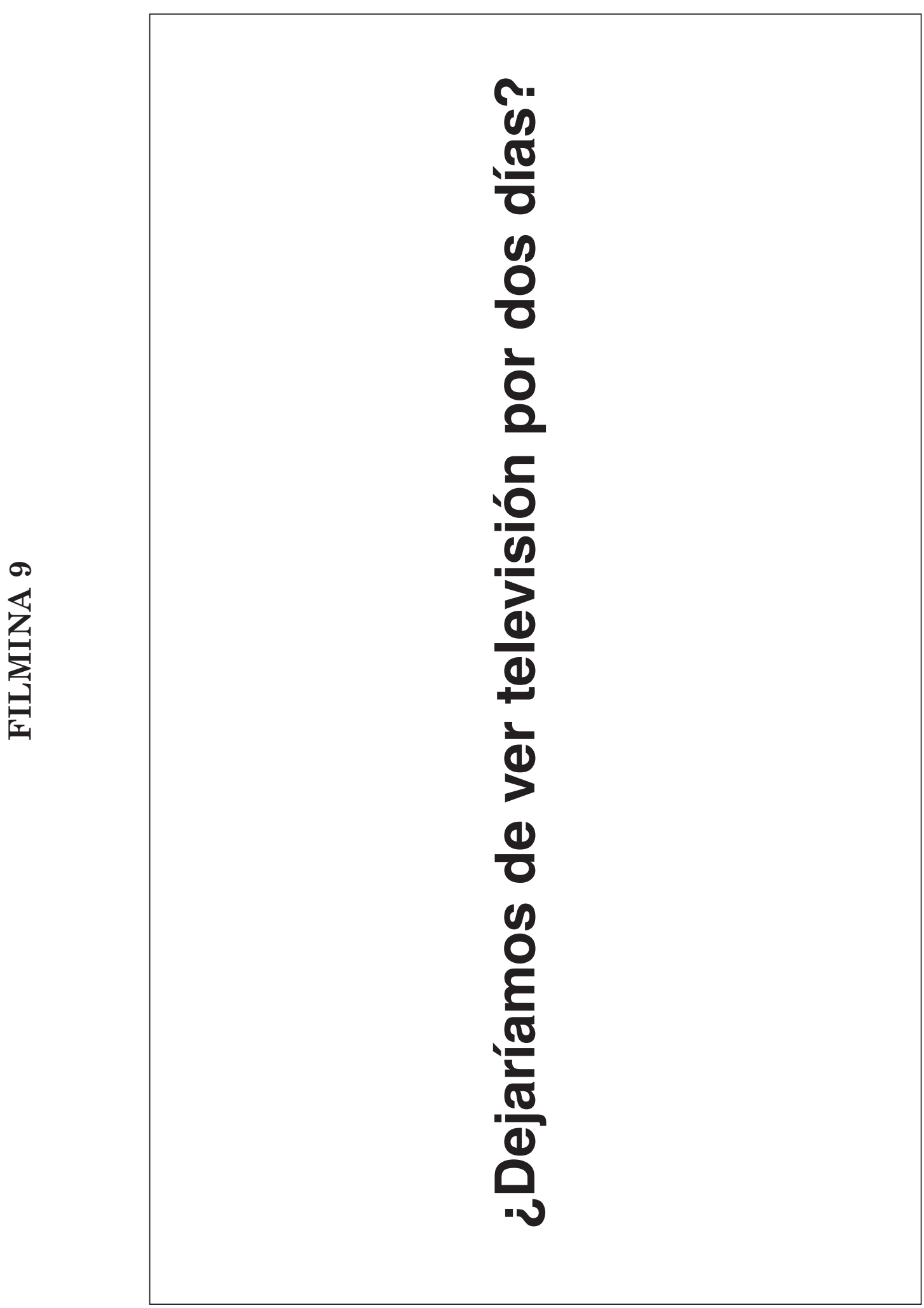




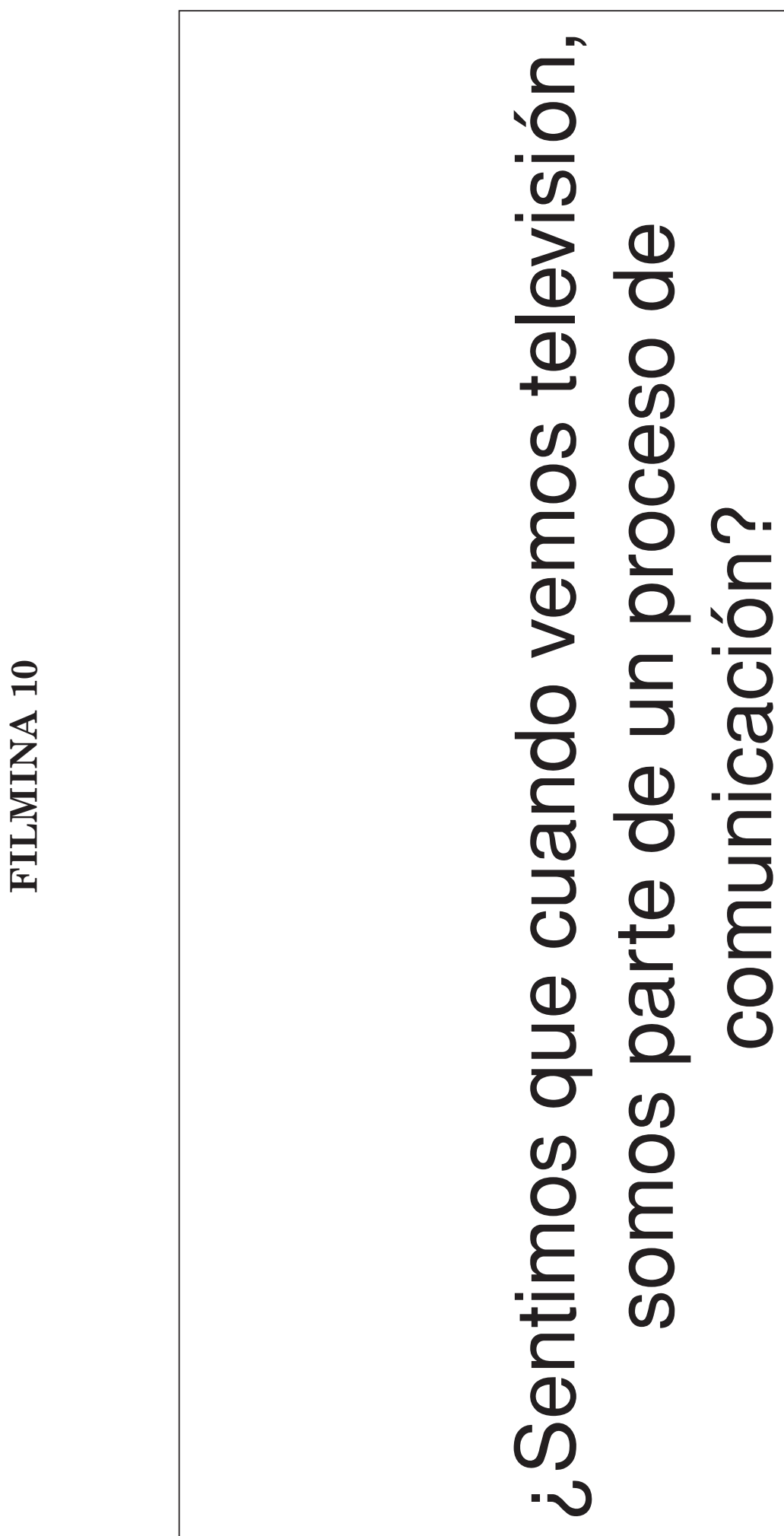




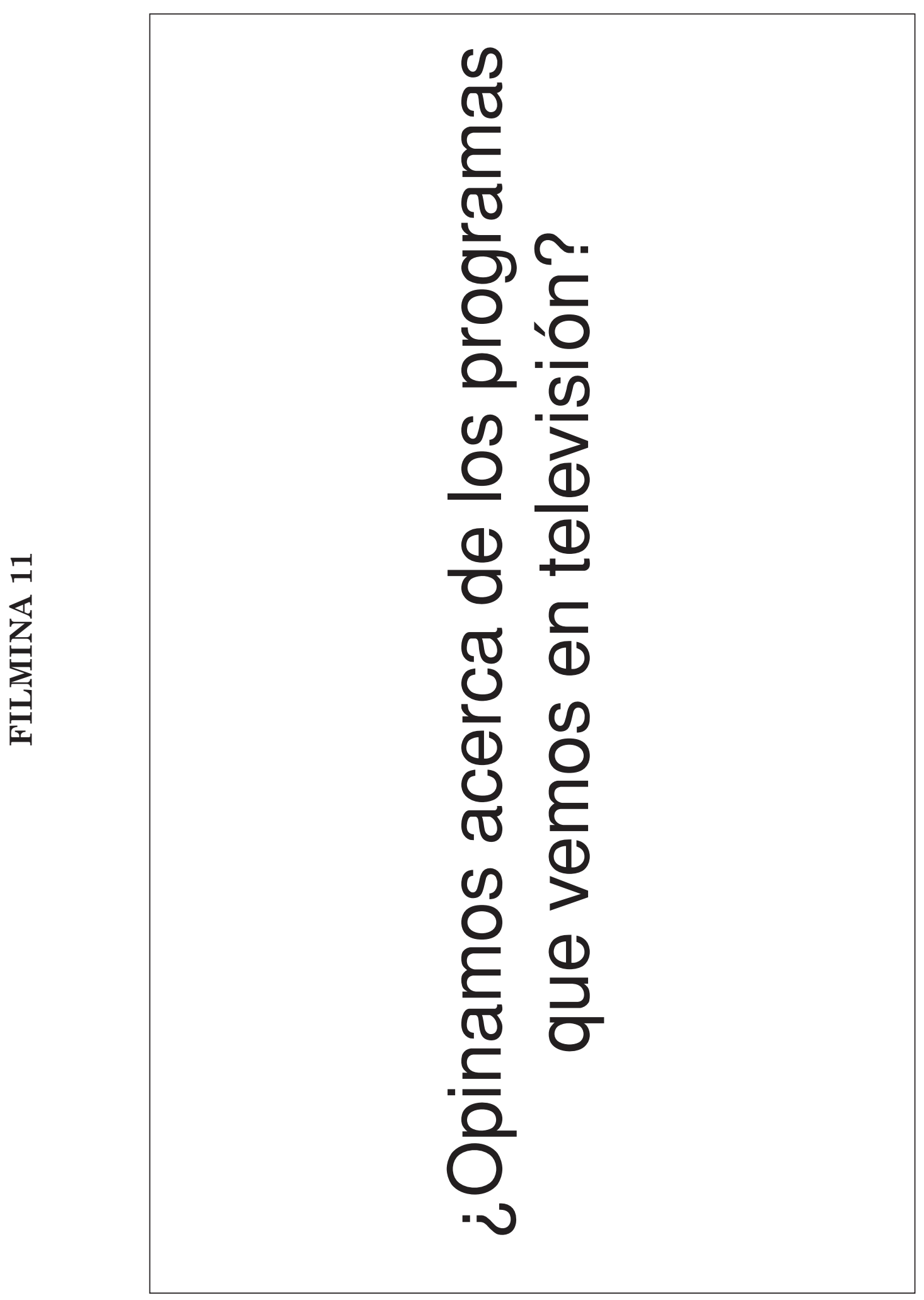




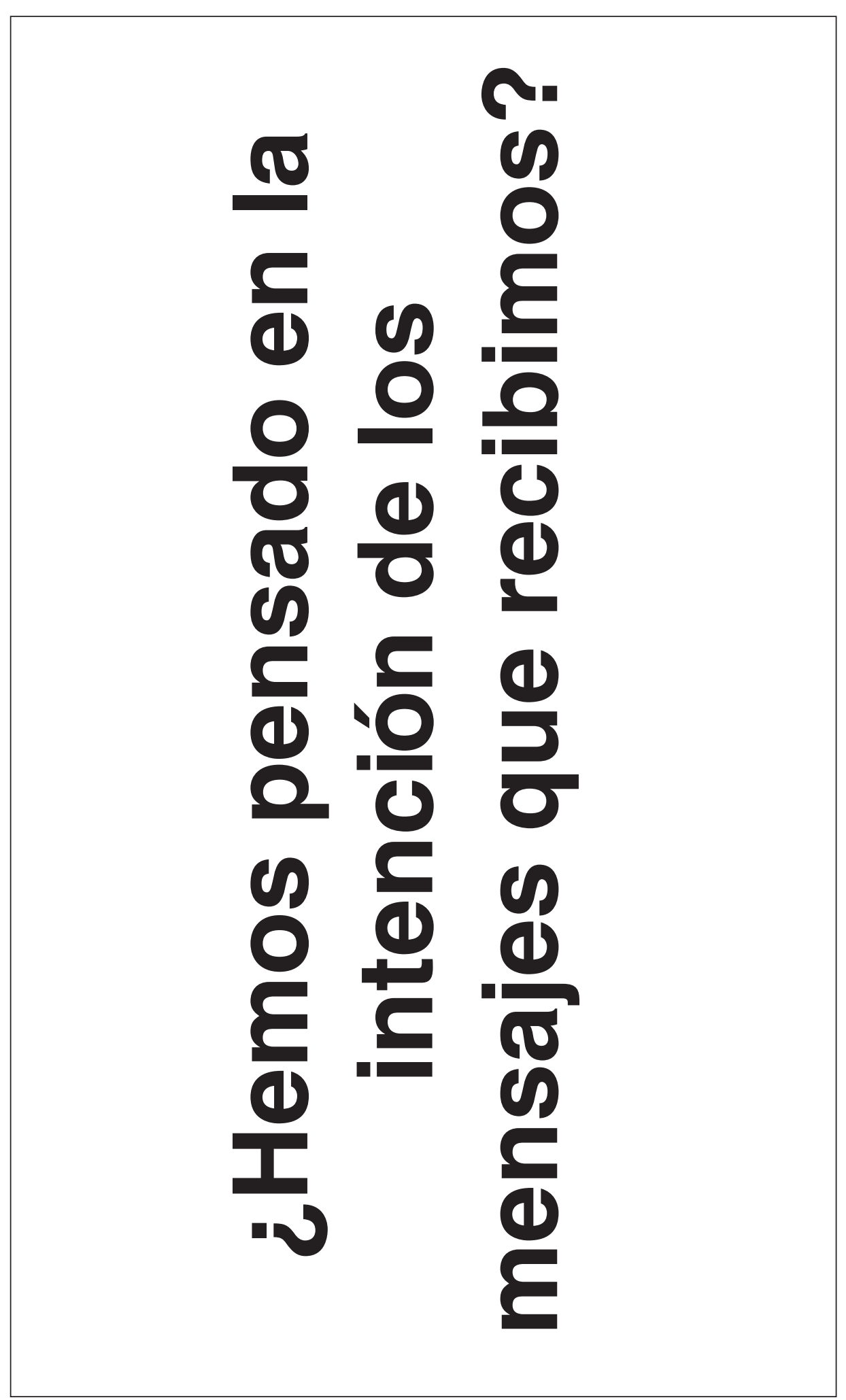




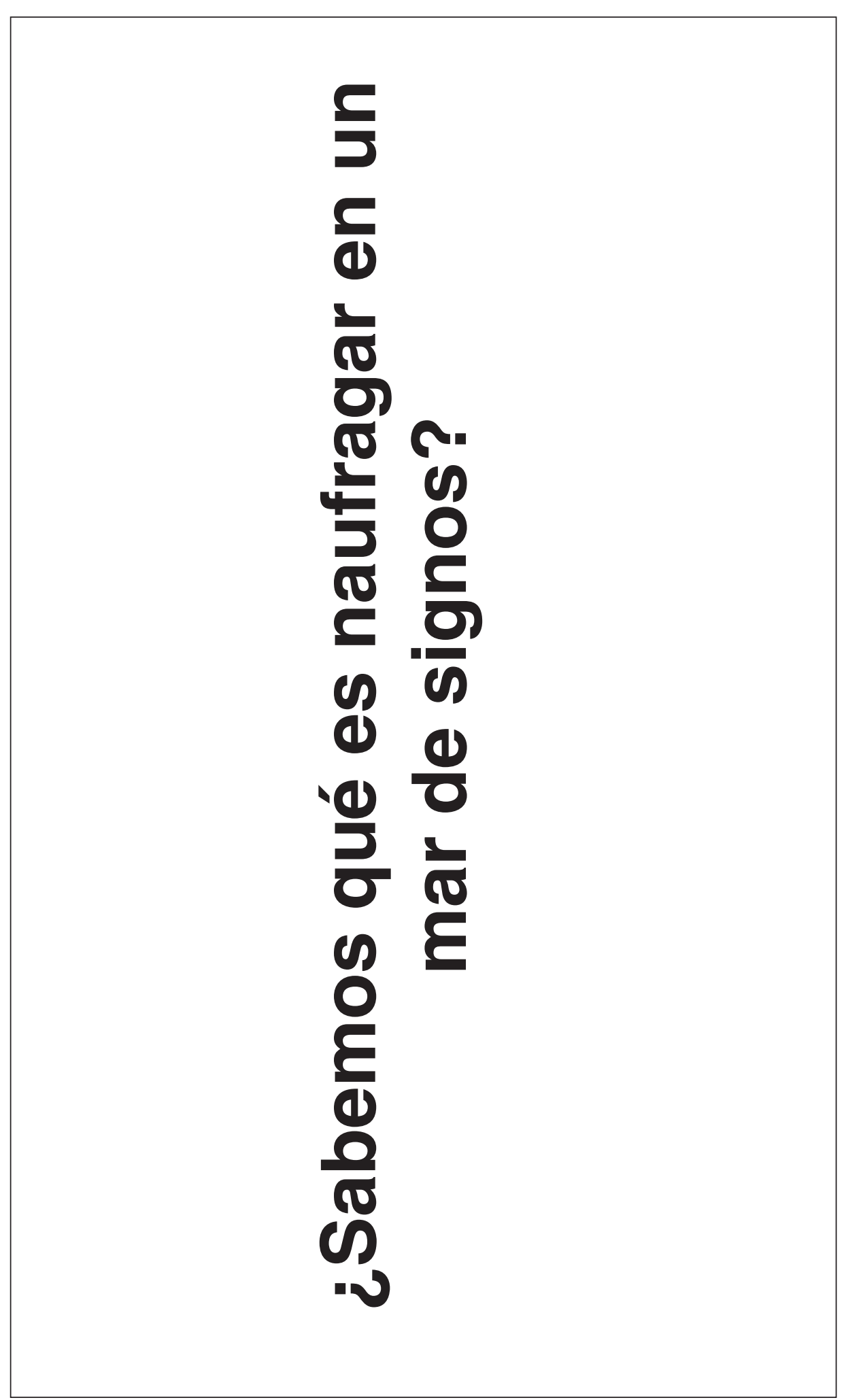




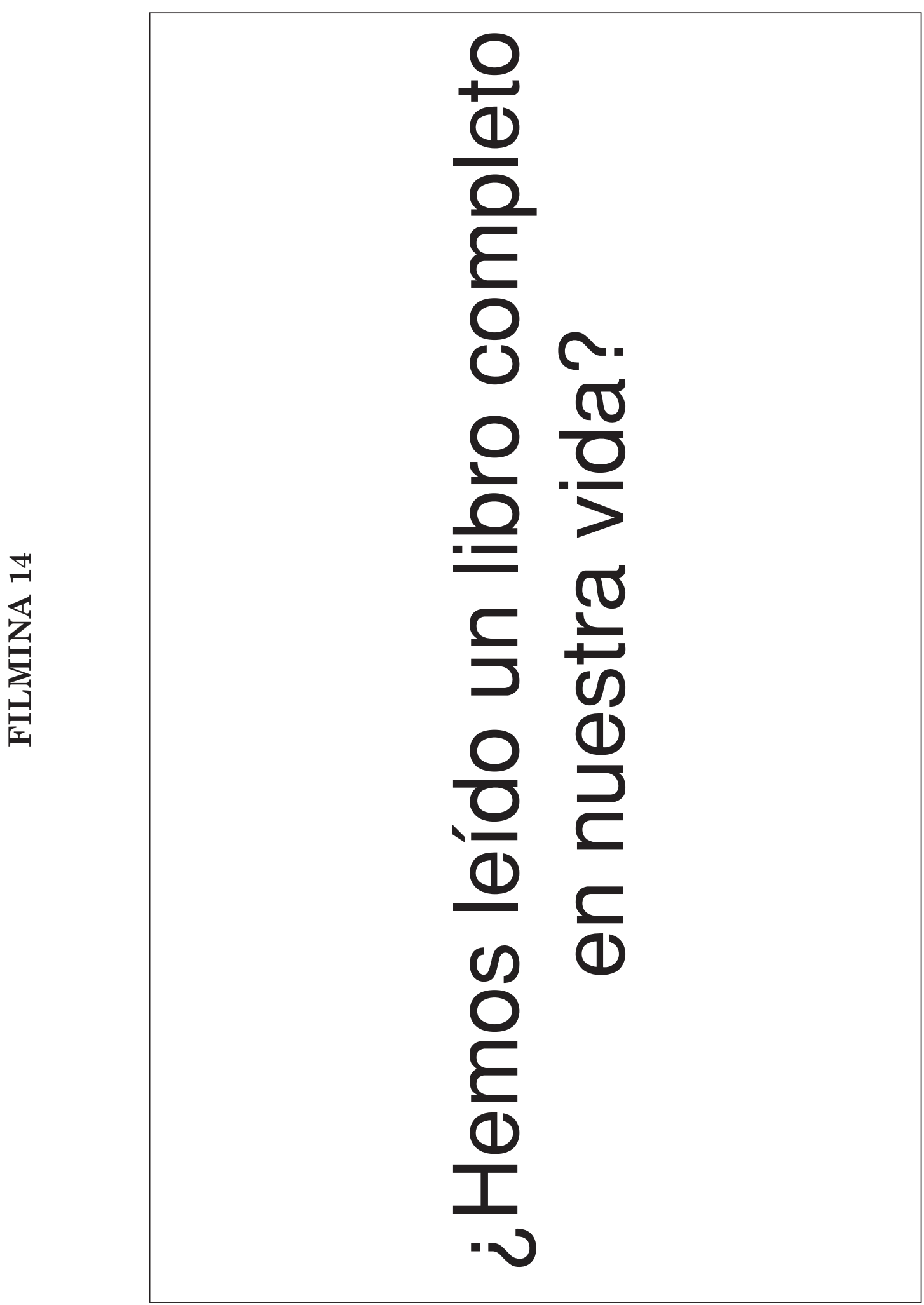




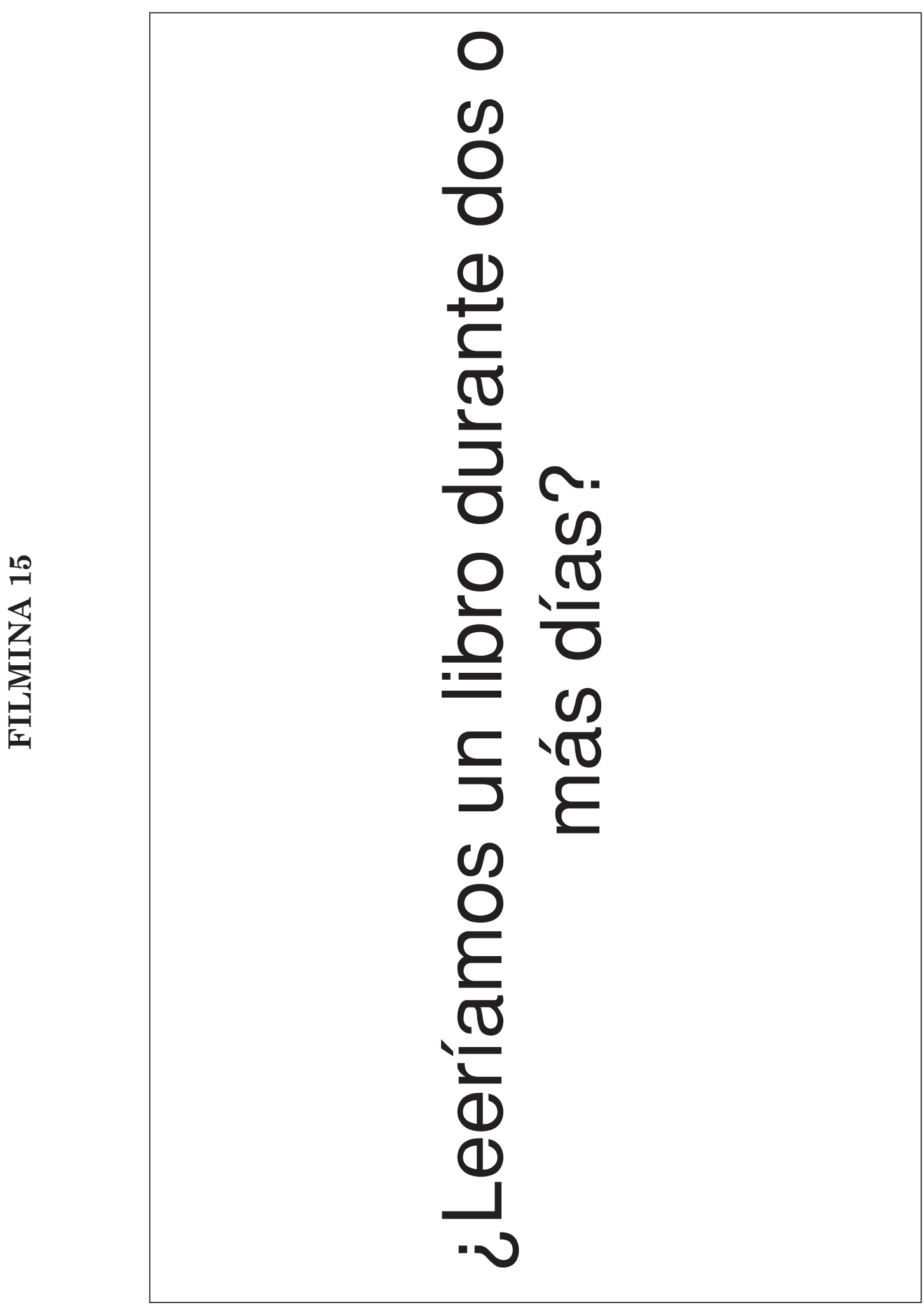




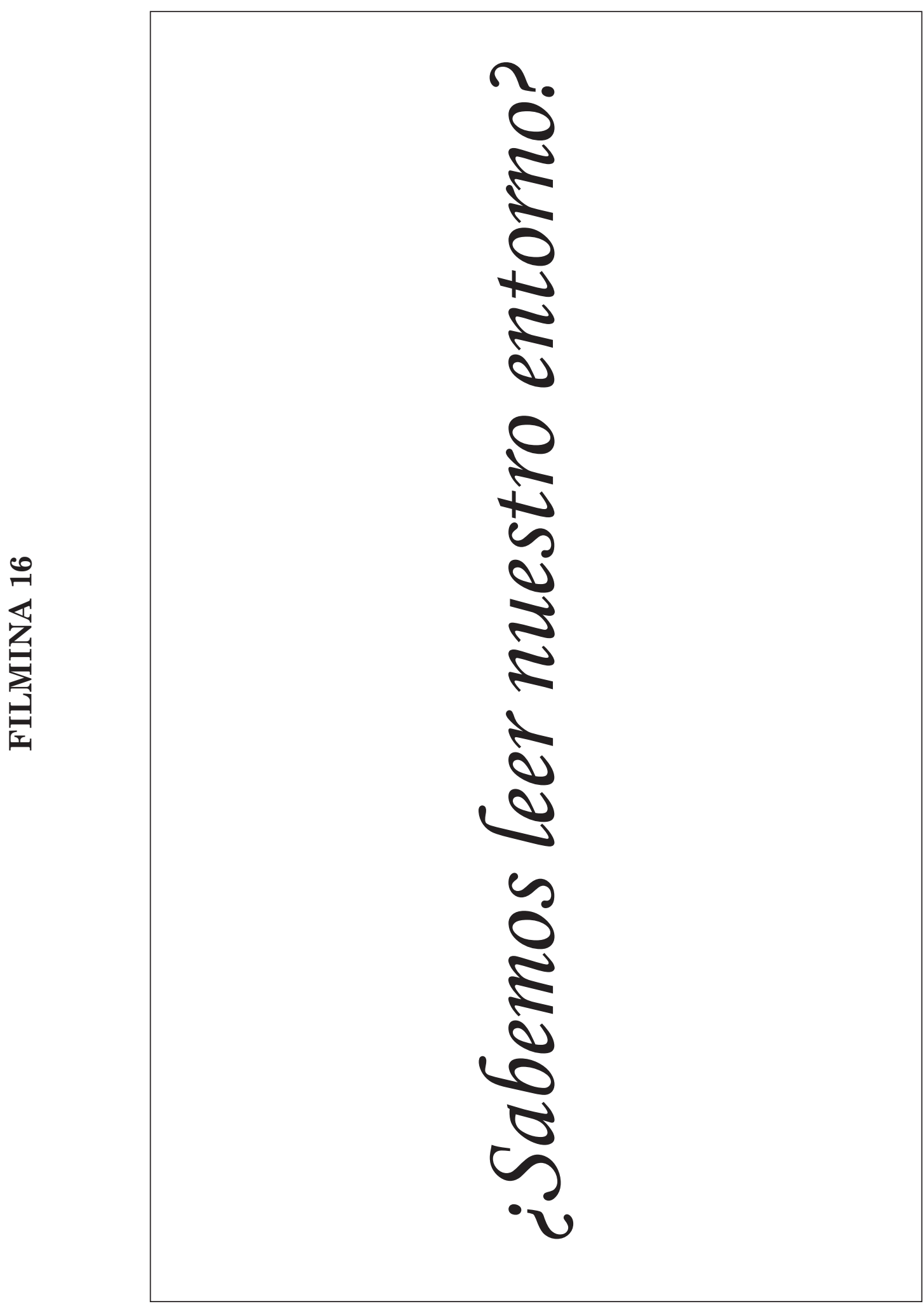




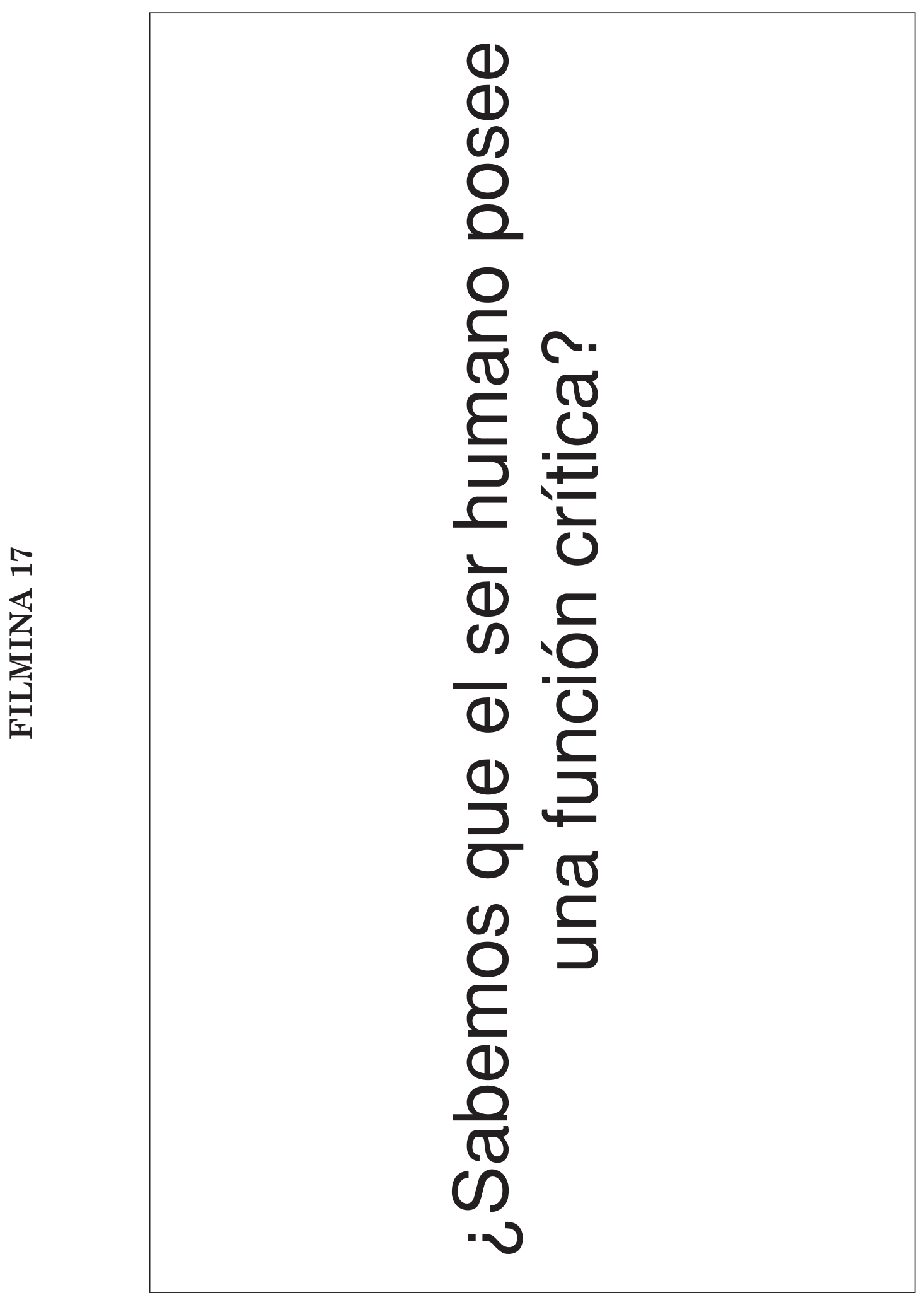




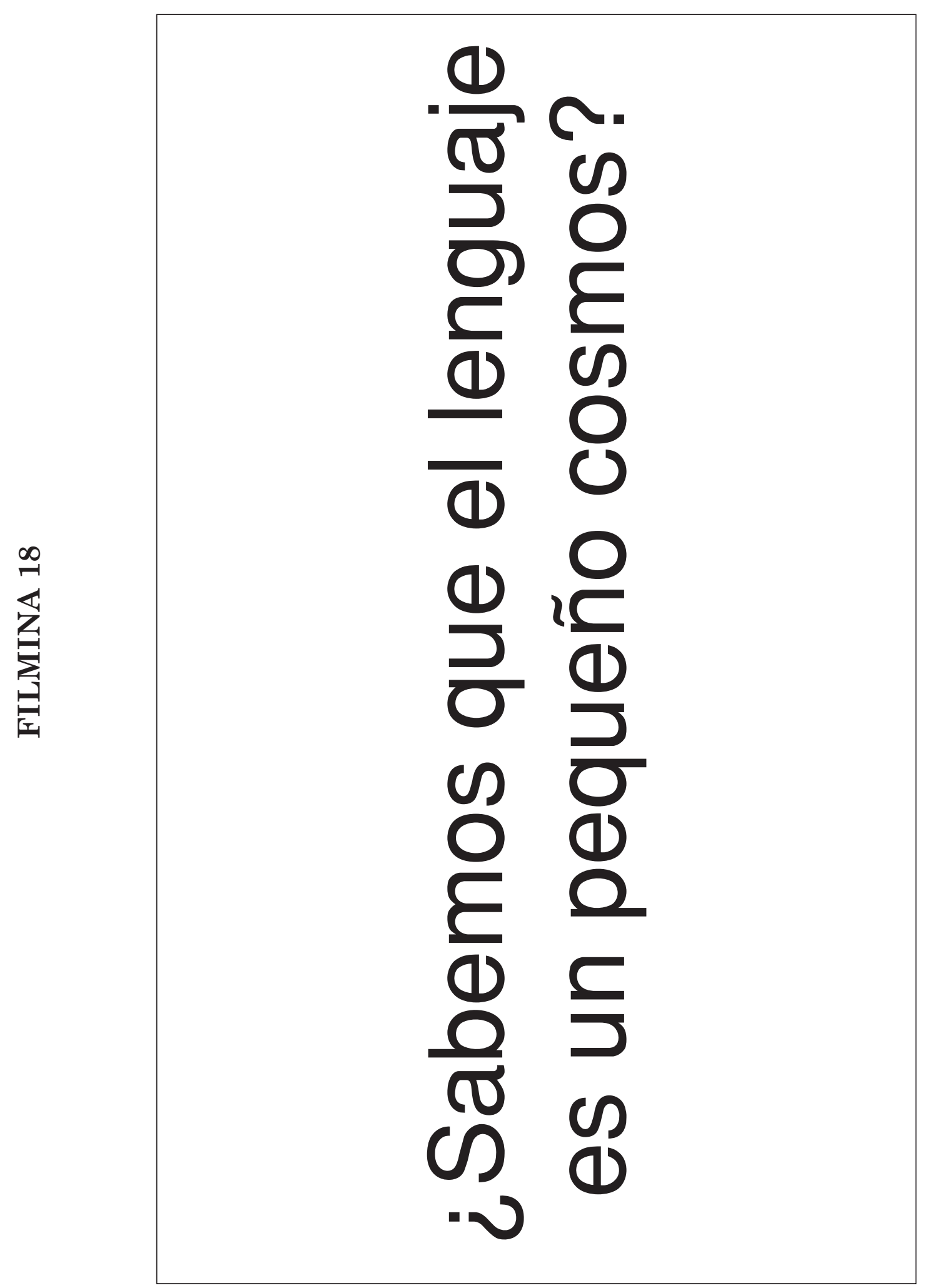




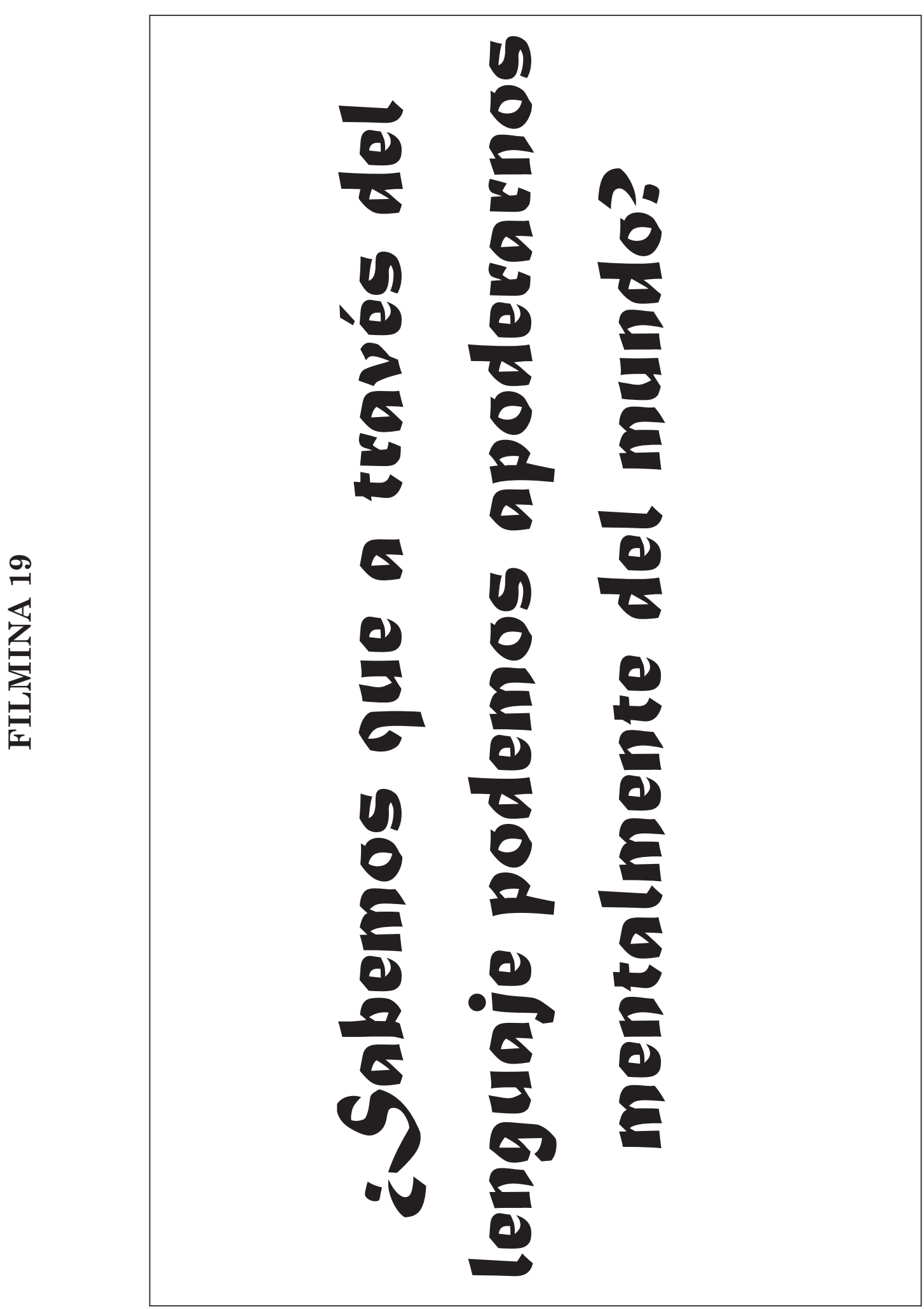


$\underbrace{4}$
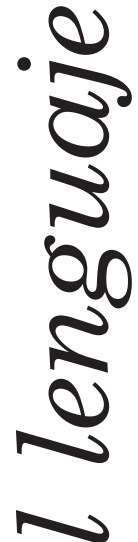

ט
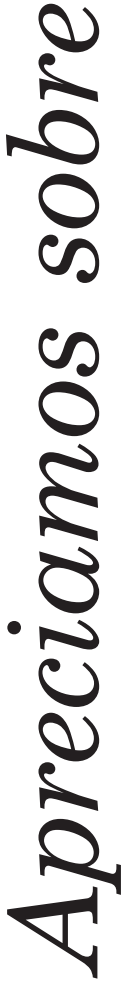


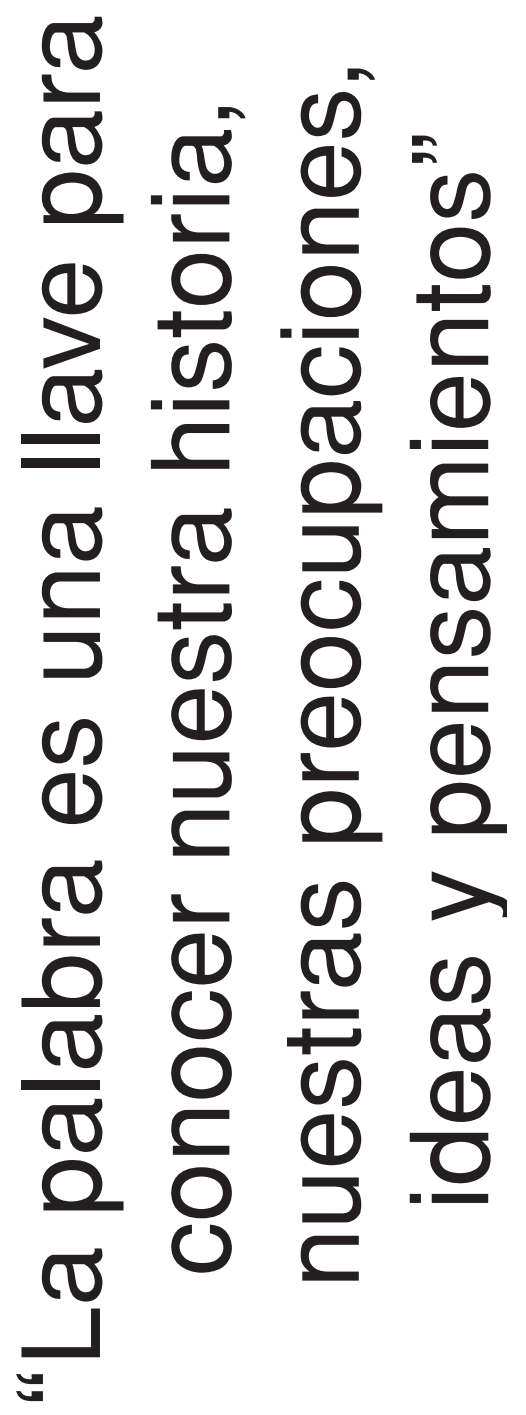




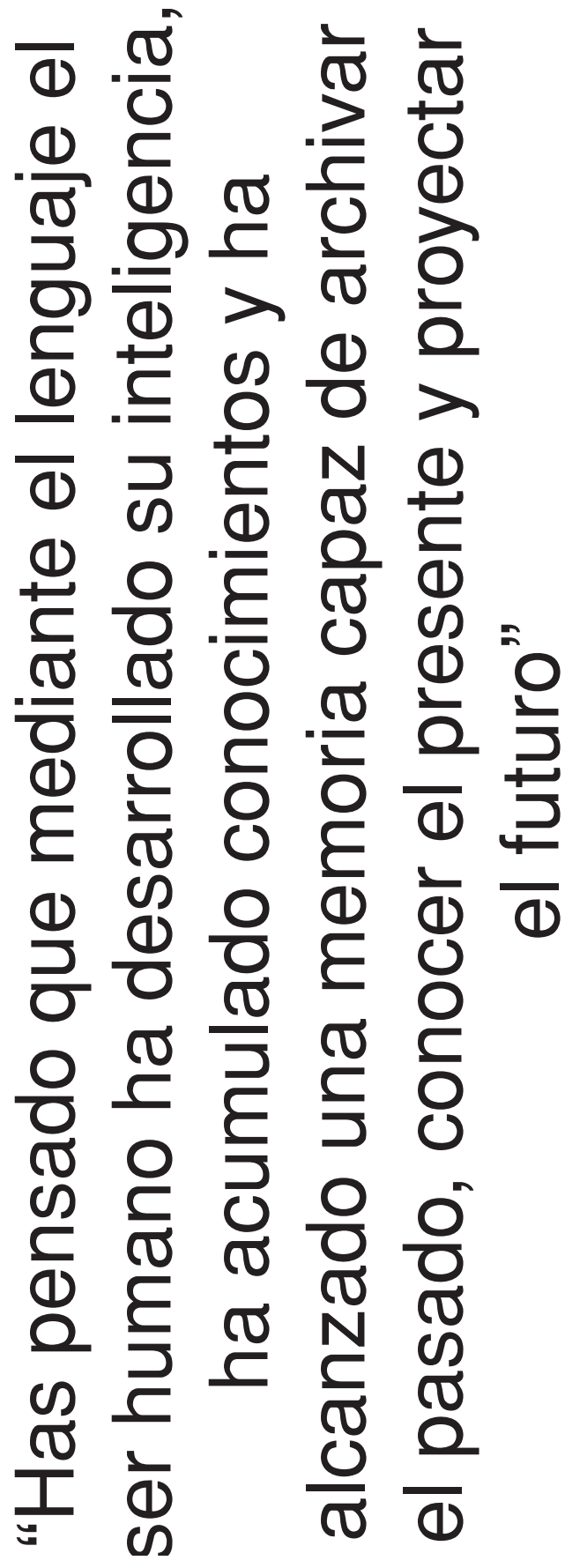


$\underline{\sigma}$

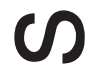

(1)

음

등

은

(1)

כ

z 


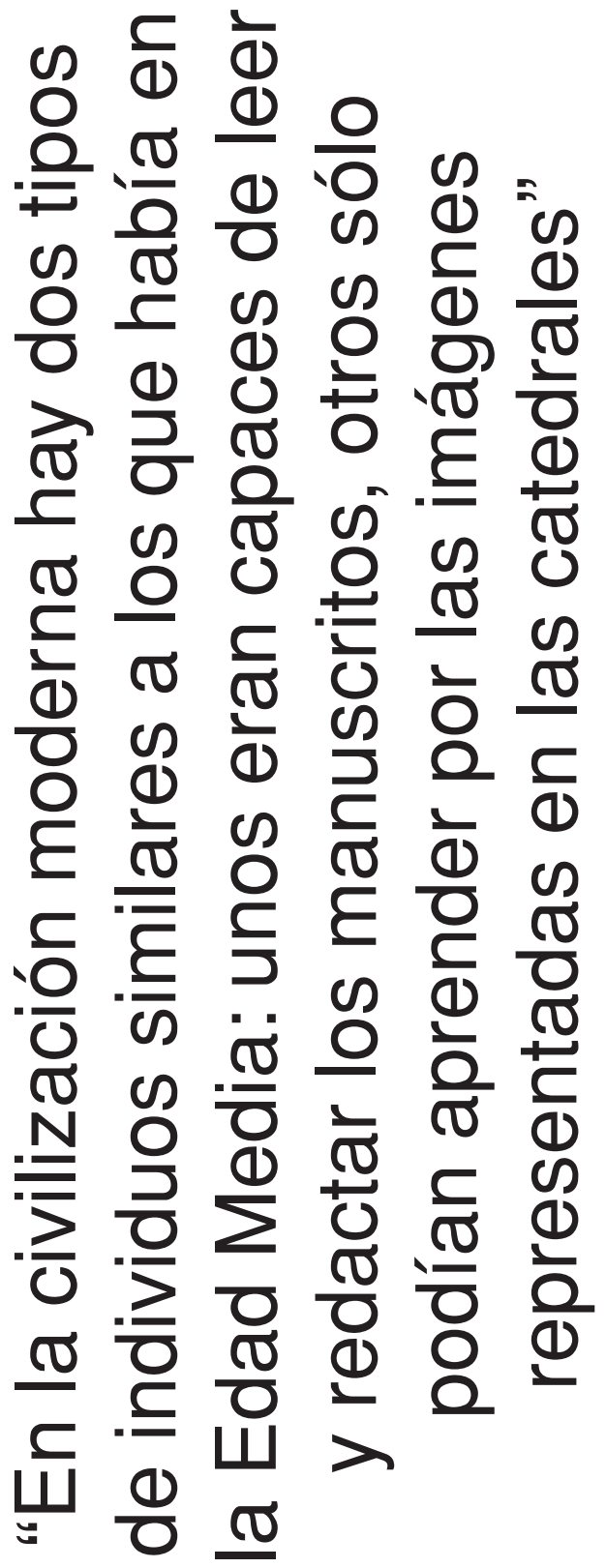



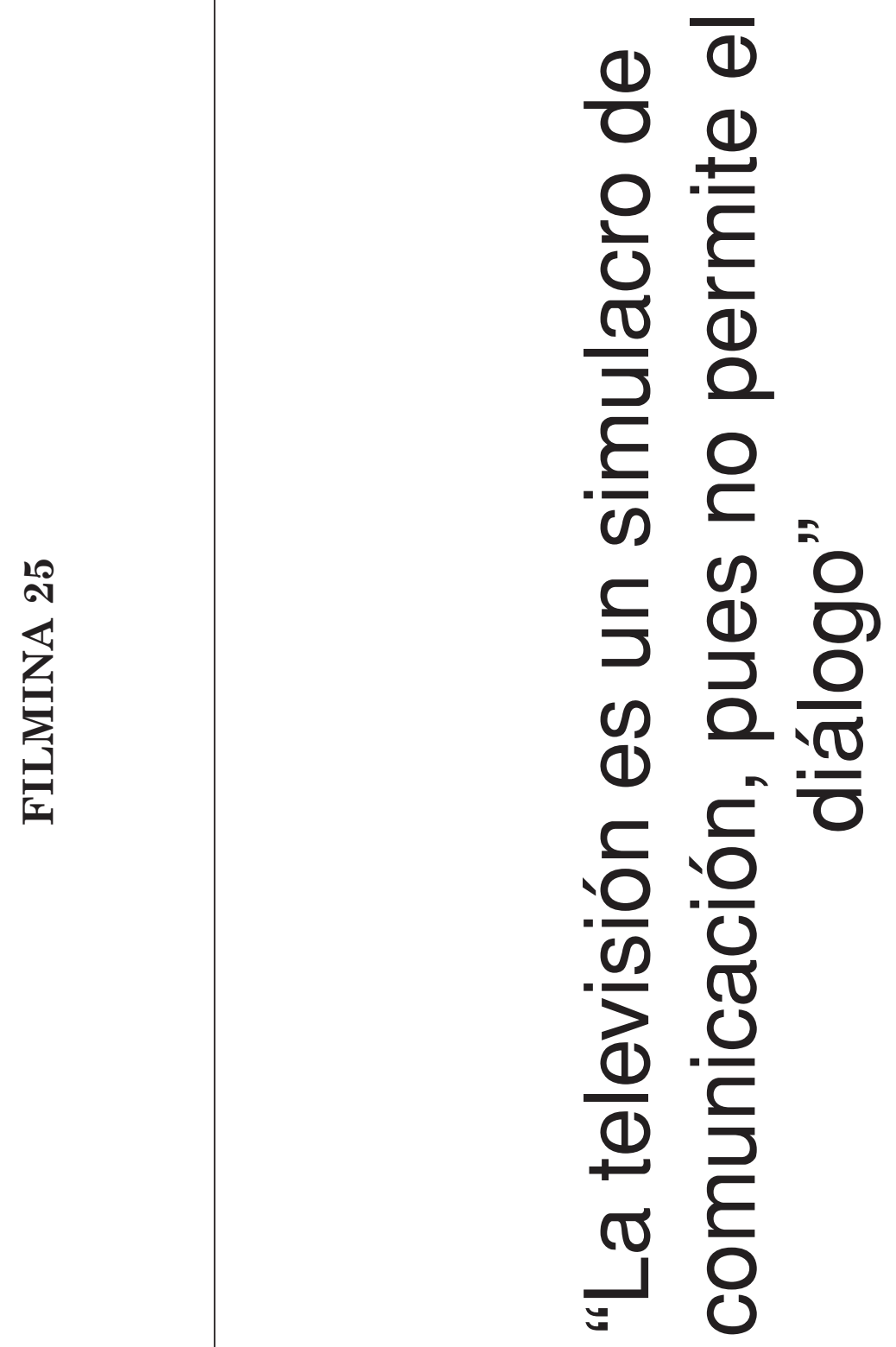
宸

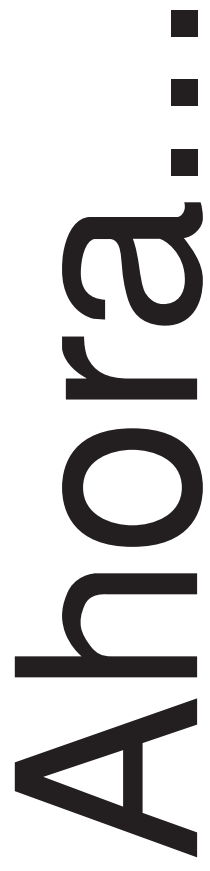




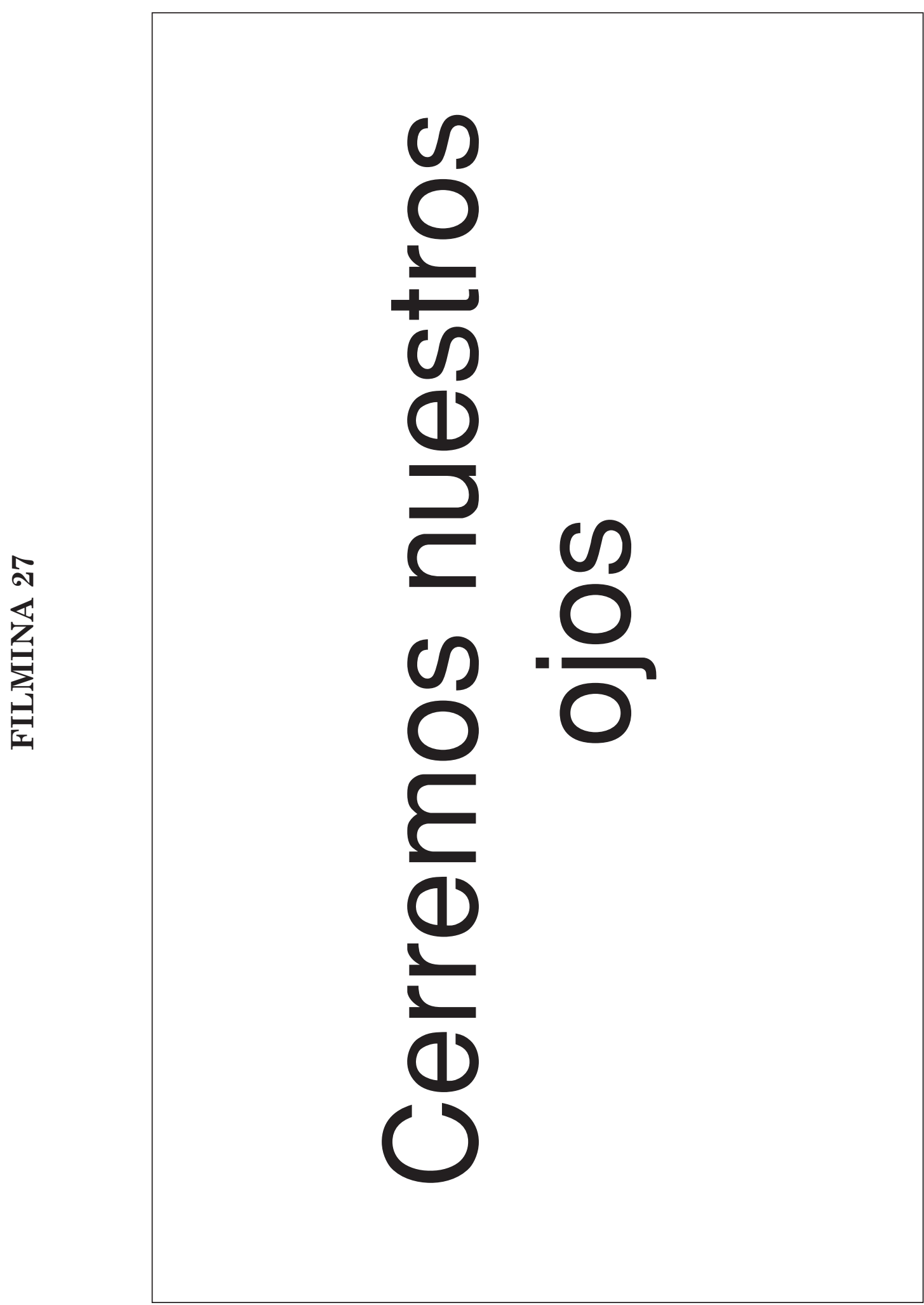




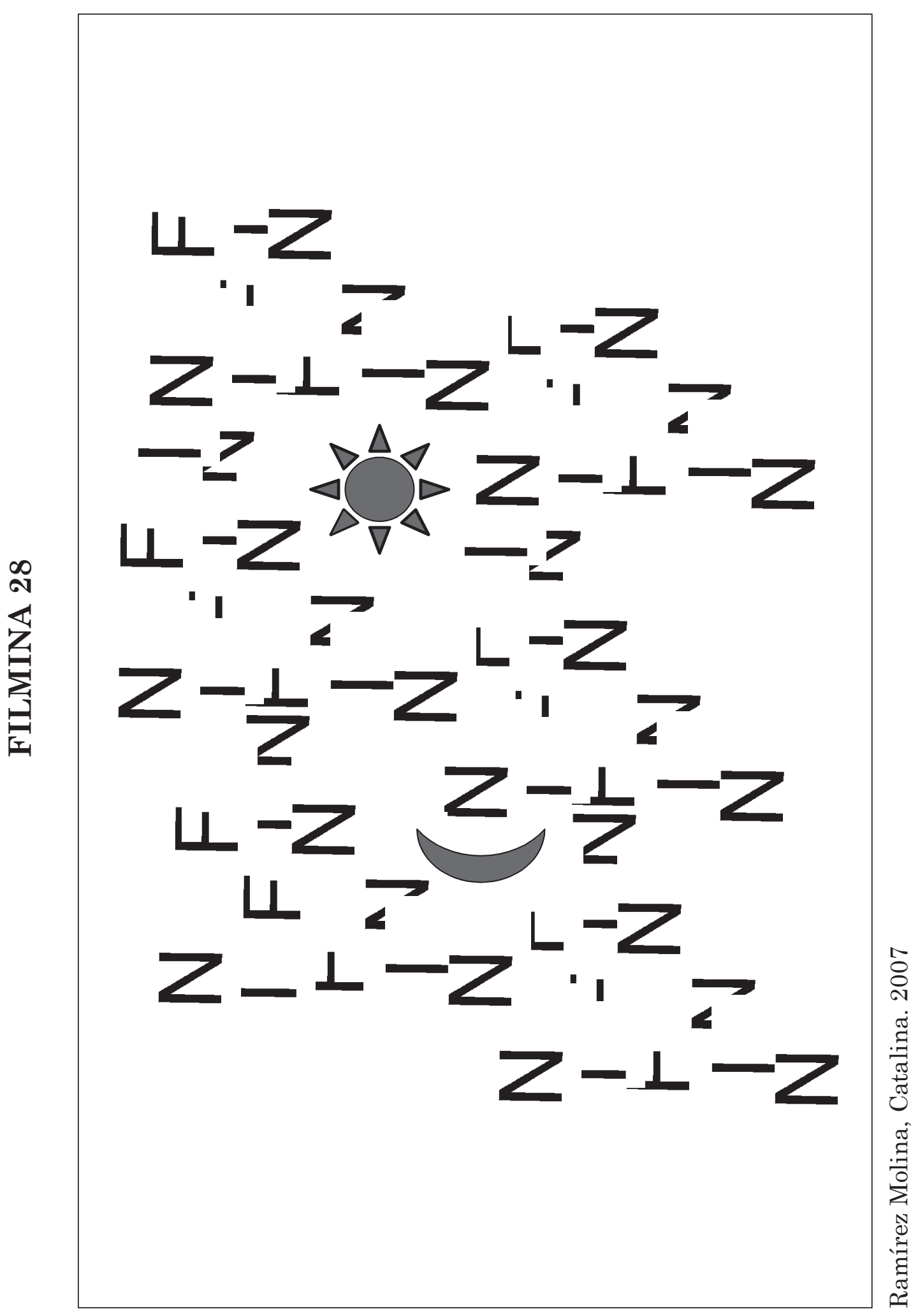


